\title{
Molecular Genetics of Relapsed Diffuse Large B-Cell Lymphoma: Insight into Mechanisms of Therapy Resistance
}

\author{
Madeleine R. Berendsen ${ }^{1,2}$, Wendy B. C. Stevens ${ }^{3}$, Michiel van den Brand ${ }^{1,4}$, \\ J. Han van Krieken ${ }^{1}$ and Blanca Scheijen ${ }^{1,2, *(D)}$ \\ 1 Department of Pathology, Radboud University Medical Center, 6525GA Nijmegen, The Netherlands; \\ Madeleine.Berendsen@radboudumc.nl (M.R.B.); Michiel.vandenBrand@radboudumc.nl (M.v.d.B.); \\ Han.vanKrieken@radboudumc.nl (J.H.v.K.) \\ 2 Radboud Institute for Molecular Life Sciences, 6525GA Nijmegen, The Netherlands \\ 3 Department of Hematology, Radboud University Medical Center, 6525GA Nijmegen, The Netherlands; \\ Wendy.Stevens@radboudumc.nl \\ 4 Pathology-DNA, Rijnstate Hospital, 6815AD Arnhem, The Netherlands \\ * Correspondence: Blanca.Scheijen@radboudumc.nl
}

Received: 26 October 2020; Accepted: 26 November 2020; Published: 28 November 2020

Simple Summary: Many patients with the aggressive cancer diffuse large B-cell lymphoma (DLBCL) still respond poorly to treatment and suffer from relapsed or refractory disease. The identification of gene mutations that are responsible for the outgrowth of the relapsed tumor is crucial to understand the underlying mechanisms of therapy resistance. In this review, we provide a comprehensive overview of the affected genes and their biological functions in the context of therapy resistance. Furthermore, we discuss novel therapeutic strategies to treat patients with relapsed disease. We expect that the identification of these gene alterations in routine diagnostics holds great potential in guiding future therapy strategies in DLBCL.

\begin{abstract}
The majority of patients with diffuse large B-cell lymphoma (DLBCL) can be treated successfully with a combination of chemotherapy and the monoclonal anti-CD20 antibody rituximab. Nonetheless, approximately one-third of the patients with DLBCL still experience relapse or refractory $(\mathrm{R} / \mathrm{R})$ disease after first-line immunochemotherapy. Whole-exome sequencing on large cohorts of primary DLBCL has revealed the mutational landscape of DLBCL, which has provided a framework to define novel prognostic subtypes in DLBCL. Several studies have investigated the genetic alterations specifically associated with R/R DLBCL, thereby uncovering molecular pathways linked to therapy resistance. Here, we summarize the current state of knowledge regarding the genetic alterations that are enriched in R/R DLBCL, and the corresponding pathways affected by these gene mutations. Furthermore, we elaborate on their potential role in mediating therapy resistance, also in connection with findings in other B-cell malignancies, and discuss alternative treatment options. Hence, this review provides a comprehensive overview on the gene lesions and molecular mechanisms underlying $R / R$ DLBCL, which are considered valuable parameters to guide treatment.
\end{abstract}

Keywords: diffuse large B-cell lymphoma; relapse; therapy resistance; mutational analysis

\section{Introduction}

Diffuse large B-cell lymphoma (DLBCL) is the most common type of non-Hodgkin lymphoma (NHL) and represents a heterogenous malignancy with respect to molecular alterations, morphology, clinical behavior and treatment response [1,2]. DLBCL can arise de novo or through transformation from 
an indolent B-cell neoplasm [3]. Due to the aggressive character of DLBCL, this lymphoid malignancy grows rapidly, which tends to involve both nodal and extranodal sites, including stomach, testis and central nervous system [4]. Current standard first-line treatment involves several cycles of R-CHOP (rituximab, cyclophosphamide, doxorubicin, vincristine, and prednisolone) immunochemotherapy, where the addition of rituximab has led to a significantly increased survival of patients with DLBCL [5-7]. Despite this improvement, approximately $25-30 \%$ of patients with DLBCL still suffer from relapse and $10 \%$ show refractory disease, where outcome of relapsed/refractory (R/R) DLBCL remains poor $[5,8]$. Most DLBCL relapses occur within two years after diagnosis [8]. However, late relapses after 5 years still occur in a fraction of DLBCL patients, and are linked to a favorable International Prognostic Index (IPI) score, limited-stage disease and extranodal involvement at diagnosis [9-12]. Treatment of R/R DLBCL after initial therapy consists of intensified high-dose chemotherapy regimens prior to autologous stem cell transplantation (ASCT) when eligible. Alternatively, these relapsed patients may receive novel therapeutic modalities, such as cellular immunotherapy.

In order to understand the mechanisms that underly immunochemotherapy resistance in B cell malignancies, the genetic defects and biological processes associated with inferior treatment response are currently being investigated. In particular, deep sequencing of R/R DLBCL samples has provided new insight into the affected genes that contribute to the occurrence of the relapse-initiating clone. This review summarizes the current knowledge on the genetic lesions and underlying mechanisms associated with R/R DLBCL, and aims to provide an integrated framework of relevant targets for therapeutic intervention of $R / R$ DLBCL.

\section{Molecular Classifications of DLBCL}

In an attempt to improve treatment outcome prediction and identify patients that may benefit from precision guided therapy, several molecular DLBCL classifications have been established. One of the earlier molecular classifications of DLBCL was based on gene expression profiling (GEP) related to the cell-of-origin, which resulted in the identification of two subtypes that comprise $80-85 \%$ of the cases: the activated B-cell like type $(\mathrm{ABC})$ and the germinal center B-cell like type (GCB), with the remaining cases termed unclassified $[13,14]$. ABC/GCB classification has been further finetuned for formalin-fixed paraffin embedded (FFPE) tissue samples by other platforms, including Lymph2Cx (Nanostring) $[15,16]$. Patients with ABC-type DLBCL display an inferior overall survival (OS) as compared to GCB-type DLBCL. ABC subtype lymphomas frequently harbor mutations in the B-cell receptor (BCR) and the NF-kB pathway genes (MYD88, CD79A/B, CARD11, TNFAIP3), and display chronic active BCR signaling, whereas those of the GCB subtype commonly display $B C L 2$ and/or MYC gene rearrangements, as well as genetic lesions in EZH2 and PTEN $[17,18]$. Despite their prognostics value, tumors within these subtypes still show heterogeneity with respect to treatment outcomes, indicating the need for more refined patient stratification strategies with improved predictive value.

As recognized by the WHO in 2016, DLBCL cases with a MYC translocation in combination with a $B C L 2$ and/or BCL6 translocation are classified as high-grade B-cell lymphoma (HGBL) [19]. These malignancies are also known as double-hit (MYC/BCL2 or MYC/BCL6 translocations) and triple-hit (MYC/BCL2/BCL6 translocations) lymphomas (DHL/THL), and represent $5-10 \%$ of DLBCL patients [20,21]. Interestingly, the majority of these lymphomas belong to the favorable GCB subtype, but show inferior outcome after R-CHOP treatment, substantiating the importance of identifying these patients. In addition, $20-35 \%$ of DLBCL cases show co-expression of MYC and BCL2 by immunohistochemistry in the absence of chromosomal translocations, which represent "double expressor" lymphomas (DEL) also associated with poor clinical outcome, but are mainly of the ABC subtype [22]. Recently, a 104-gene double-hit GEP signature (DHITsig) has been defined, which identifies an additional subgroup of GCB-type patients besides DHL/THL translocation-positive DLBCL cases, with a poor prognosis [23].

Whole-exome sequencing (WES), gene copy number analysis and high-throughput RNA sequencing (RNA-Seq) has resulted in novel DLBCL clusters related to treatment outcome. Schmitz et al. genetically dissected DLBCL into four subtypes: MCD (co-occurrence MYD88L265P and CD79B 
mutations), BN2 (BCL6 fusions and NOTCH2 mutations), N1 (NOTCH1 mutations) and EZB (EZH2 mutations and BCL2 translocations), where BN2 and EZB subtypes showed better outcome [24]. Three of these genetic clusters were independently identified by Chapuy et al. (C1-BN2, C3-EZB, C5-MCD), with some discrepancy in clinical outcome for certain subtypes [25]. Wright et al. unified these two studies, defining seven genetic DLBCL clusters which correspond to different clinical outcome and potential therapeutic targeting, with about $40 \%$ of the DLBCL cases remaining unclassified [26]. In parallel, a British consortium performed targeted sequencing of 293-genes and defined five molecular subtypes [27], demonstrating partial overlap with the initial two WES studies [24,25], which includes NOTCH2-C1-BN2, BCL2-C3-EZB, and MYD88-C5-MCD, and leaving 27\% of the DLBCL cases unclassified.

\section{Immunochemotherapy Resistance in DLBCL}

First-line DLBCL treatment involves a combination of DNA damaging agents (cyclophosphamide, doxorubicin and vincristine) and the synthetic glucocorticoid prednisolone, together with rituximab. Chemotherapy resistance prototypically relates to multidrug resistance, changes in drug metabolism, inhibition of apoptosis, enhanced DNA repair and epigenetic modifications [28], while glucocorticoid resistance in lymphoid malignancies is mediated through the modulation of cell signaling, apoptosis inhibition and gene regulation [29]. It is evident that many of the biological pathways activated in B-NHL that promote the survival of the malignant B cells may also confer drug resistance, thereby inducing R/R DLBCL (see below).

The addition of rituximab to standard chemotherapy has shown beneficial effects on DLBCL treatment outcome, but also generated specific resistance mechanisms. Rituximab exerts its therapeutic effects via binding to CD20, leading to (1) complement dependent cytotoxicity (CDC), and (2) antibody-dependent cellular toxicity (ADCC) [30]. The third anti-cancer effect involves the active induction of apoptosis by inhibiting critical pro-survival pathways, including NF-kB, p38 MAPK, $\mathrm{MEK} / \mathrm{ERK}$ and PI3K/AKT/mTORC1 pathways [31-33]. Several studies indicate that rituximab resistance mostly relates to down-regulation of CD20 expression and MS4A1(CD20) gene mutations in de novo tumors and R/R disease [34,35]. However, recent findings demonstrate that BCR signaling also affects the response to rituximab [36].

A successful approach, as shown in leukemias, to elucidate the molecular mechanisms that contribute to immunochemotherapy resistance and relapse development, involves high coverage WES analysis of tumor cell populations in both diagnosis and relapse samples. In the B-cell precursor acute lymphoblastic leukemia (BCP-ALL), IKZF1 deletions are linked to increased relapse risk [37,38], while in chronic lymphocytic leukemia (CLL), IKZF3 and TP53 have been identified as relapse drivers displaying increased mutation frequency in relapsed samples after immunochemotherapy [39]. Notably, in CLL, TP53 mutations are directly linked to chemotherapy resistance and these patients are now treated differently in order to improve treatment outcome [40-43]. These findings demonstrate the importance of identifying genetic alterations that underlie relapse and immunochemotherapy resistance in DLBCL.

\section{Clonal Evolution of Relapsed DLBCL}

The identification of relapse-associated mutations has resulted in the construction of clonal lineages from diagnosis to relapse for several cancers, including DLBCL [44-48]. Here, two patterns of genetic tumor evolution have been identified: (1) early divergence/branching evolution, in which the diagnosis and relapsed tumor share several variants, but mostly obtained additional unique somatic mutations, and (2) late-divergence/linear evolution, where the diagnosis and relapsed tumor share the majority of genetic alterations $[45,46]$. In the first scenario, already during early tumor development a subpopulation diverges, suiting a branched model that can expand into the relapsed tumor, whereas in the latter scenario, the relapsed tumor develops from a late subclone.

As described by Juskevicius et al. [47], these models of genetic evolution correspond to two different mechanisms of resistance, namely intrinsic resistance and acquired resistance. The early 
divergence/branching model correlates with intrinsic resistance, where a resistant subclonal population is already present prior to treatment. After the dominant clone is eradicated due to effective therapy strategies, the subclone evolves as the relapse-initiating clone to form the relapsed tumor. In case of acquired resistance, which fits the late-divergent/linear model, resistance develops through treatment pressure, in which the subsequent genetic instability leads to genetic evolution and the acquisition of resistant mutations $[49,50]$. In both described scenarios, genetic variants that drive the relapsed tumor are present in a significantly higher fraction of the cancer cells at relapse compared to the primary diagnosis.

\section{Genetic Alterations and Biological Pathways Selectively Enriched in R/R DLBCL}

To identify genetic alterations that are responsible for inferior treatment outcome and relapse, several studies have investigated the genetic landscape in R/R DLBCL by targeted sequencing or WES (Table 1). Relapse-enriched and relapse-specific gene mutations have been identified by comparing variant allele frequencies (VAFs) between matched diagnosis-relapse tumor samples [34,44-46,48,51-53], or by differences in prevalence of gene mutations in samples of relapsed patients as compared to independent primary DLBCL cohorts [34,44,45,48,51-53]. In addition, a few studies performed mutational analysis in the diagnostic samples of patients who displayed $R / R$ disease shortly after treatment [54,55]. Multiple studies detected genetic lesions affecting MYC, BCL2, TP53 and members of the JAK-STAT signaling pathway. Other recurrent processes involve immune escape strategies and epigenetic regulation of the tumor genome. In the next paragraphs, we will elaborate on these pathways and describe their potential role in mediating therapy resistance. 
Table 1. Relapse-associated genes in diffuse large B-cell lymphoma (DLBCL).

\begin{tabular}{|c|c|c|c|c|c|}
\hline Study & Cohort Description & Cohort Size & Method & $\begin{array}{c}\text { Genes Presenting R/R } \\
\text { Enriched Variants in Paired } \\
\text { Diagnosis-Relapse Analyses }{ }^{1}\end{array}$ & $\begin{array}{l}\text { Genes Presenting R/R Enriched } \\
\text { Variants in Comparison with } \\
\text { Independent Primary Cohorts }{ }^{2}\end{array}$ \\
\hline Jiang et al. 2014 [46] & Paired D-R samples & $\begin{array}{c}N=7 \\
(4 / 7 \text { tLY })\end{array}$ & WES & $B C L 2, E P 300, B 2 M, C D 58$ & \\
\hline \multirow[b]{2}{*}{ Morin et al. 2016 [51] } & Paired D-R/R samples & $\begin{array}{c}N=12 \\
(9 / 12 \text { tLY })\end{array}$ & Targeted panel & $\begin{array}{l}\text { STAT6, EZH2, FOXO1, SOCS1, } \\
\text { KMT2D, CD79B, NFKBIE }\end{array}$ & \\
\hline & $\begin{array}{c}\mathrm{R} / \mathrm{R} \text { samples } \\
\text { (taken after at least one cycle of } \\
\text { immuno-chemotherapy) }\end{array}$ & $N=25$ & $\begin{array}{c}\text { WES } \\
\text { Targeted panel }\end{array}$ & & $\begin{array}{l}\text { R/R samples compared with } \\
\text { independent primary cohort: } \\
\text { KMT2C, MPEG1, NFKBIZ, CCND3, } \\
\text { STAT6, TP53, MYC, FOXO1 }\end{array}$ \\
\hline \multirow[b]{2}{*}{ Juskevicius et al. 2016 [45] } & $\begin{array}{c}\text { Paired D-R samples } \\
\text { (relapse following complete remission) }\end{array}$ & $N=20$ & Targeted panel & $\begin{array}{c}\text { KMT2D, MEF2B, TET2, PRDM1, } \\
\text { PTEN, EBF1 }\end{array}$ & \\
\hline & $\begin{array}{l}\text { Non-relapsing samples } \\
\text { (taken at diagnosis } \geq 4 \text { years relapse-free) }\end{array}$ & $N=20$ & Targeted panel & & $\begin{array}{l}\text { Diagnosis samples of relapsed } \\
\text { patients compared with } \\
\text { non-relapsing samples: } \\
\text { KMT2D, BCL2, PTEN, PRDM1, } \\
\text { MCL1, CARD11 }\end{array}$ \\
\hline Melchardt et al. 2016 [44] & Paired D-R/R samples & $N=24$ & $\begin{array}{c}\text { Targeted } \\
\text { panel }\end{array}$ & TP53, RB1, EZH2 & $\begin{array}{c}\text { Diagnosis samples of R/R patients } \\
\text { compared with independent } \\
\text { primary cohort: } \\
\text { NOTCH1, SMARCA4, PIM1, } \\
\text { KMT2D } \\
\text { R/R samples compared with } \\
\text { independent primary cohort: } \\
\text { TP53, BCL2, MYC, RB1, ATM, EZH2 }\end{array}$ \\
\hline Park et al. 2016 [55] & $\begin{array}{c}\text { Diagnosis samples of responsive } \\
\text { (CR maintained }>1 \text { year interval) } \\
\text { vs. } \\
\text { refractory patients ( }<1 \text { year interval) }\end{array}$ & $\begin{array}{l}N=7 \text { responsive } \\
N=6 \text { refractory }\end{array}$ & WES & & $\begin{array}{c}\text { TP53, MYD88, B2M, PRDM15, } \\
\text { FNBP4, AHR, CEP128, BRE, } \\
\text { SORCS3, WDFY3, CXXC4 }\end{array}$ \\
\hline Mareschal et al. 2016 [54] & $\begin{array}{l}\text { Diagnosis samples of } R / R \text { patients } \\
\text { ( } \leq 1 \text { year interval) }\end{array}$ & $N=14$ & WES & & $\begin{array}{c}\text { ABC: MYD88, TBL1XR1, IRF4, } \\
\text { CD58, PCDH17, HIST1H1B, } \\
\text { HIST1H1C, HIST1H1D } \\
\text { GCB: BCL2, DUSP2, NFKBIA, } \\
\text { BTG2, MEF2B }\end{array}$ \\
\hline
\end{tabular}


Table 1. Cont.

\begin{tabular}{|c|c|c|c|c|c|}
\hline Study & Cohort Description & Cohort Size & Method & $\begin{array}{c}\text { Genes Presenting R/R } \\
\text { Enriched Variants in Paired } \\
\text { Diagnosis-Relapse Analyses }{ }^{1}\end{array}$ & $\begin{array}{l}\text { Genes Presenting R/R Enriched } \\
\text { Variants in Comparison with } \\
\text { Independent Primary Cohorts }{ }^{2}\end{array}$ \\
\hline \multirow[b]{2}{*}{ Greenawalt et al. 2017 [52] } & Paired D-R/R samples & $N=8$ & WES & CREBBP, BCL2 & \\
\hline & $\begin{array}{c}\mathrm{R} / \mathrm{R} \text { samples } \\
\text { (after 1-8 cycles of } \mathrm{R}-\mathrm{CHOP} \text { ) }\end{array}$ & $N=47$ & & & $\begin{array}{c}\mathrm{R} / \mathrm{R} \text { samples compared with } \\
\text { independent primary cohort: } \\
C R E B B P, B C L 2, T P 53, B 2 M, \\
M Y C, B T K\end{array}$ \\
\hline Nijland et al. 2018 [53] & $\begin{array}{c}\text { Paired D-R/R samples } \\
\text { (patients that received 6-8 cycles of } \\
\text { R-CHOP) }\end{array}$ & $N=6$ & WES & $\begin{array}{l}\text { SOCS1, PIM1, MYC, BCL2, } \\
\text { BIRC3, BTG2, IRF4, SGK1, B2M, } \\
\text { CALR, HLA-DR, HLA-B }\end{array}$ & $\begin{array}{c}\text { Diagnosis and relapsed samples o } \\
\text { R/R cohort compared with } \\
\text { independent primary cohort: } \\
\text { SOCS1, PIM1,MYC, HLA-DR, } \\
H L A-B\end{array}$ \\
\hline \multirow[t]{2}{*}{ Rushton et al. 2020 [34] } & $\begin{array}{c}\text { Paired } \\
\text { D-R/R samples } \\
\text { (tissue biopsies/ctDNA) }\end{array}$ & $N=57$ & Targeted panel & $\begin{array}{c}\text { MS4A1, KMT2D, CD79B, } \\
\text { TBL1XR1, ZFP36L1, CARD11, } \\
\text { BTG2, MYC, SOCS1, PIM1, } \\
\text { TNFAIP3, MYD88, HIST1H1E, } \\
\text { NFKBIE, TNFRSF14, BCL2, } \\
\text { IRF4, SGK1, GNA13, B2M, } \\
\text { FBXO11, TP53, CD58, EP300 }\end{array}$ & \\
\hline & $\mathrm{R} / \mathrm{R}$ ctDNA & $N=135$ & & & $\begin{array}{c}\text { R/R samples compared with } \\
\text { independent primary cohort: } \\
\text { KMT2D, TP53, CREBBP, FOXO1, } \\
\text { NFKBIE, MS4A1 }\end{array}$ \\
\hline \multirow[b]{2}{*}{ Isaev et al. 2020 [48] } & $\begin{array}{c}\text { Paired } \\
\text { D-CNS relapse samples }\end{array}$ & $N=5$ & WES & PIM1, ETV6 & \\
\hline & $\begin{array}{c}\text { Diagnosis samples of systemic and CNS } \\
\text { relapsed patients } \\
(<1 \text { year interval) } \\
\text { vs. non-relapsing patients } \\
\text { ( } \geq 5 \text { years relapse free })\end{array}$ & $\begin{array}{c}N=62 \\
\text { systemic relapse } \\
N=72 \\
\text { CNS relapse } \\
N=89 \\
\text { Non-relapsing }\end{array}$ & $\begin{array}{l}\text { Targeted panel } \\
\text { WES }\end{array}$ & & $\begin{array}{c}\text { Diagnosis samples of CNS relapse } \\
\text { compared with non-relapsing } \\
\text { samples: } \\
\text { MYD88, CD79B, PIM1 } \\
\text { Diagnosis samples of refractory } \\
\text { disease or systemic relapse } \\
\text { compared with non-relapsing } \\
\text { samples: } \\
\text { TP53, MYD88, BCL2, HIST1H1E, } \\
\text { HIST1H1C, FOXO1, BTG1, CIITA, } \\
\text { CD58, ZFP36L1 }\end{array}$ \\
\hline
\end{tabular}

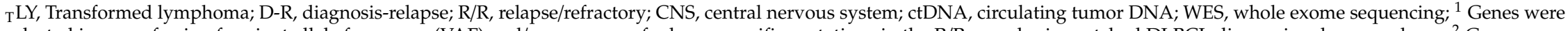
selected in case of gain of variant allele frequency (VAF) and/or presence of relapse-specific mutations in the R/R samples in matched DLBCL diagnosis-relapse analyses; ${ }^{2}$ Genes were selected in case of higher mutational frequency in diagnosis and/or relapsed samples of R/R cohort compared with primary DLBCL cohort(s). 


\subsection{MYC, BCL2, and BCL6 Gene Alterations}

As described earlier, HGBL with gene rearrangements affecting MYC, BCL2 and/or BCL6, and DEL are linked to inferior treatment response $[19,20]$, although DEL has a better prognosis compared to DHL or THL DLBCL [19,56-58]. DEL are more frequent among R/R DLBCL (45\%) as compared to primary DLBCL (20-35\%), and associated with inferior outcome [59,60]. Additionally, DHITsig-positive cases are more common in diagnosis samples of relapsed DLBCL patients $(\sim 60 \%)$, compared to non-relapsing patients (30\%) [48]. In contrast, the relative frequencies of DHL and THL in R/R DLBCL are similar to newly diagnosed DLBCL $(\sim 10 \%)[60,61]$.

\subsubsection{BCL2}

The anti-apoptotic protein BCL2 promotes cell survival in B cells, and many BCL2 family members play a crucial role in modulating cellular stress responses [62,63]. Independent studies investigating paired diagnosis-relapse DLBCL demonstrate that several single nucleotide variants (SNVs) and copy number aberrations (CNA) in BCL2 are enriched in relapse, while certain variants are relapse-specific $[34,44,46,52,53]$. Likewise, in a non-paired diagnosis and R/R DLBCL cohort studies, $B C L 2$ is more frequently altered in relapse, exhibiting almost doubled mutational frequencies $[44,52]$. Specifically, an increase in 5'UTR mutations is observed (6\% vs. $17 \%)$, a region that contains various elements that control its expression [52]. Due to its anti-apoptotic properties, enhanced BCL2 expression corresponds to a poor prognosis in DLBCL [64,65].

Mechanisms underlying its increased expression levels relate to $\mathrm{t}(14 ; 18)(\mathrm{q} 32 ; \mathrm{q} 21) \mathrm{IGH}-B C L 2$ translocation [66,67], and constitutive NF-kB activation [68]. Diagnosis DLBCL samples of patients who relapse express higher levels of BCL2 than those without relapse, which has not been observed for either MYC or BCL6 expression [45]. Furthermore, BCL2 mutations are more prevalent in primary samples of relapsing patients than those of non-relapsing patients $[45,48]$. These relapse-associated SNVs targeting $B C L 2$ probably result in gain-of-function, thereby increasing its anti-apoptotic properties. The majority of these BCL2 alterations most likely play a direct role in R-CHOP therapy resistance and the outgrowth of the relapse-initiating clone (Figure 1). As such, BCL2 family members are known to confer drug resistance to various chemotherapeutic agents in hematological malignancies $[69,70]$. Studies involving rituximab and/or CHOP resistant B-NHL cell lines reported the increased expression of anti-apoptotic BCL2 family members, including BCL2, BCL- $\mathrm{X}_{\mathrm{L}}$ or MCL1, while specific inhibitors targeting these proteins abrogated these effects [71,72]. Notably, increased MCL1 expression is more frequently observed in ABC-DLBCL than the GCB subtype, which may relate to the inferior prognosis of this subtype [73].

\subsubsection{MYC}

The MYC oncogene is a key player in B cell development and maturation, as it regulates the expression of multiple genes related to cell growth, differentiation, proliferation and survival [74]. Overexpression of MYC is observed in $30-50 \%$ of primary DLBCL [75,76], while missense mutations are observed in 16\% of DLBCL patients [77]. MYC rearrangements relate to significantly inferior 5-year progression-free survival (PFS) and OS after R-CHOP treatment in patients with DLBCL [78], and are more common in diagnosis samples of primary treatment failure patients (31\%) [79], although this overrepresentation is not observed in R/R DLBCL patient samples (17\%) [61]. On the other hand, $M Y C$ mutations are more frequently observed at the time of relapse in paired diagnosis-relapse DLBCL samples, including several unique mutations that are not present at initial diagnosis $[34,46,53]$. Additionally, in non-paired diagnosis and R/R cohorts, MYC mutations are more frequently detected in relapsed DLBCL $[44,51-53]$. As such, these relapse-enriched MYC mutations are often located in the N-terminus and are considered to reinforce MYC's oncogenic potential [51,80]. In addition, significant amplification of gene regions impacting MYC have been observed in R/R DLBCL, and not in independent DLBCL primary cohorts [52]. 


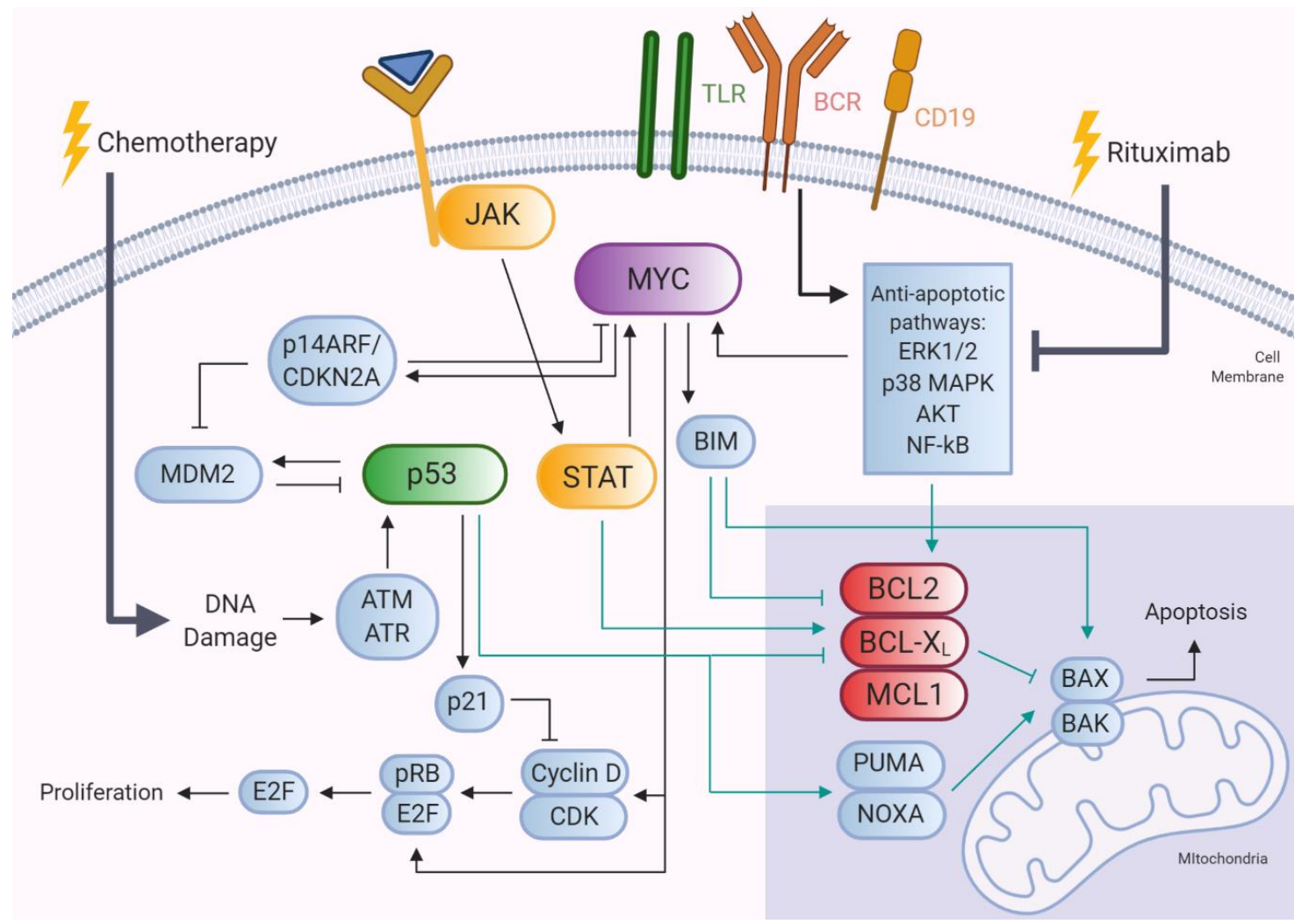

Figure 1. Relapse-associated genes and pathways interacting with R-CHOP immunochemotherapy. DNA damage induced by chemotherapy activates the $\mathrm{p} 53$ pathway, thereby inhibiting cell proliferation by p21 upregulation and inducing apoptosis through regulation of BCL2-members. Rituximab inhibits several anti-apoptotic pathways leading to downregulation of anti-apoptotic BCL2 members, and regulation of MYC. MYC, in its turn, exerts multiple functions, including regulation of the p53 pathway and pro-apoptotic executioner proteins, BAX and BAK, and the cell cycle. Activation of the JAK-STAT pathway affects proliferation and apoptosis of lymphoma cells. TLR, Toll-like receptor; BCR, $\mathrm{B}$ cell receptor. Turquoise lines indicate regulation of the BCL2 family members.

MYC primarily induces apoptosis upon overexpression, which includes the activation of the p53 pathway through the suppression of $p 14 A R F / C D K N 2 A$ gene expression [81]. MYC also upregulates the pro-apoptotic protein BIM, and indirectly downregulates BCL2, BCL- $\mathrm{X}_{\mathrm{L}}$ and MCL1 $[82,83]$. However, during lymphomagenesis, the pro-apoptotic activity of MYC is counteracted by TP53 mutations and BCL2 overexpression. Hence, the oncogenic and chemoresistance phenotype of p53 and BCL2 is enhanced by MYC gene alterations [81,84].

\subsubsection{BCL6}

BCL6 facilitates the proliferation of germinal center B cells after T-cell dependent antigen stimulation and represses differentiation into plasma and memory cells [85]. Distinct genetic abnormalities have been described that lead to increased BCL6 expression [86,87], and BCL6 chromosomal translocations are present in $\sim 25 \%$ of DLBCL [24,25]. BCL6 gene rearrangements have been associated with poor OS in DLBCL in a meta-analysis of 22 studies, which are prognostic mainly following rituximab-containing regimens [88]. In contrast to BCL2 and $M Y C, B C L 6$ alterations other than gene rearrangements are not reported as enriched in relapsed DLBCL. Interestingly, TP53 mutations are frequently observed in MYC/BCL2-rearranged lymphomas, while this is not the case for MYC/BCL6 lymphomas [89]. As BCL6 is a known regulator of p53 [90], and p53 in turn 
is implicated in regulation of BCL6 [91], it could be hypothesized that for relapse formation TP53 alterations are preferred drivers, alleviating the requirement for certain BCL6 gene alterations.

\subsection{TP53 Gene Alterations}

Tumor suppressor p53 is involved in multiple key functions to guard the human genome against oncogenic transformation, and promotes cell cycle arrest, senescence, DNA repair and pro-apoptotic signaling under conditions of cellular stress [92,93]. TP53 represents the most commonly mutated gene in human cancer [94], where mutant p53 evokes cell cycle dysregulation, genomic instability and uncontrolled cell proliferation. In most cases, missense mutations occur throughout the TP53 gene, often clustering in the DNA-binding domain, which predominantly yield loss of wild-type p53 function, although gain-of-function activity has been described for several p53 mutants $[95,96]$. In DLBCL, TP53 gene aberrations are detected in $35 \%$ of the patients and are mostly associated with inferior prognosis [97-100]. These include both TP53 mutations (21\%) and focal del (17p) TP53 gene deletions (29\%), which frequently co-occur resulting in bi-allelic inactivation [25,101]. In the DLBCL classification tool of Wright et al, TP53 mutations and deletions cluster within the A53 genetic subtype with a 5 -year OS of 63\%, representing an intermediate risk group [26]. However, the British multicenter study showed a variable impact of TP53 mutations on prognosis between the molecular subtypes, conferring no effect in the NOTCH2 group, but poor prognosis in the MYD88 subtype [27].

Most importantly, there is a significantly increased prevalence of TP53 gene aberrations at relapse [34,44,51], which provides clear evidence that disruption of p53 function is an important driver in DLBCL relapse. Overall, mutations affecting TP53 are clonally stable during the progression from diagnosis to relapse [34]. The increase in TP53 mutations involves both the outgrowth of subclonal populations already present at diagnosis and the acquisition of novel relapse-specific mutations. Interestingly, ultra-deep sequencing has revealed the presence of TP53 mutations at very low allele frequency at time of diagnosis [44]. This suggests that therapy resistance conferred by TP53 mutations more often represents an intrinsic property of the initial tumor rather than de novo acquired [44]. Similarly, the frequency of TP53 mutations in primary and relapsed samples of R/R DLBCL cohorts is higher than in independent primary DLBCL samples [34,44,48,51,52]. In a large cohort of $R / R$ DLBCL $(n=135)$, TP53 mutations were identified in $51 \%$ of the patients, whereas only $21 \%$ of primary DLBCL $(n=1200)$ showed TP53 mutations, highlighting the importance of TP53 alterations in relapse initiation [34]. Convergence to p53-mediated resistance in relapse samples also involves genetic alterations in p53 upstream regulators, such as the high occurrence of CDKN2A (INK4A/p14ARF) gene deletions ( $43 \%$ in relapse vs $15 \%$ in primary diagnosis), and mutations ( $30 \%$ in relapse vs $10 \%$ in primary diagnosis) $[25,46,53,102,103]$.

The presence of TP53 mutations is known to cause resistance to a wide variety of anti-cancer drugs, including alkylating agents, anthracyclines, antimetabolites, and antiestrogens [104]. The underlying mechanism is dependent on the mode of action of the drug, but for many of the cytotoxic drugs, mutant p53 interferes with the DNA damage response pathway. In p53 wild type cells, DNA damage activates protein kinases ATM and ATR, which leads to phosphorylation of p53, thereby increasing its protein stability. In this way, p53 is able to induce cell cycle arrest or apoptosis after failed cell-cycle repair through the transcriptional upregulation of cyclin dependent kinase inhibitor p21 and pro-apoptotic proteins, PUMA and NOXA, which initiate apoptosis through mitochondrial release of caspase-activating factors [43,82]. However, it is evident that p53 regulates cell survival in multiple ways, including indirect inhibition of BCL2 and MCL1 expression, and protein displacement of BCL2 family members within the mitochondria [105]. In addition, p53 impacts the immune recognition of tumor cells by regulating antigen presentation by MHC-I, as well as the expression of NKG2D ligands and PD-L1 via the transcriptional target miR-34a [106]. Hence, mutant p53 promotes interference with the apoptotic pathway, impairment of DNA repair and attenuated immune responses, which may lead to the acquisition of additional genetic aberrations and evasion of immune eradication. Together, 
this advocates an important role of TP53 gene alterations in mediating immunochemotherapy resistance of DLBCL.

\subsection{Mutations Targeting JAK-STAT Signaling}

Activation of the Janus kinase (JAK)/signal transducer and activator of transcription (STAT) pathway occurs downstream of cytokine and growth factor receptor signaling and induces cell proliferation, differentiation and cell survival [107]. JAKs are a family of four nonreceptor tyrosine kinases (JAK1, JAK2, JAK3 and TYK2), which upon activation induce phosphorylation and nuclear translocation of STAT transcription factors, of which seven members exist (STAT1-STAT4, STAT5A, STAT5B and STAT6) $[108,109]$. Fine-tuning of the JAK/STAT pathway occurs at several levels, including a negative feedback loop involving proteins of the suppressor of cytokine signaling (SOCS) family. In lymphoid cells, activated STAT proteins are known to regulate the expression of critical genes involved in cell survival and proliferation, such as BCL-X $\mathrm{L}_{\mathrm{L}}$ and MCL1, JUN and MYC [110].

In DLBCL, mutations affecting the JAK/STAT pathway have been detected as relapse-enriched genetic alterations, including JAK1, STAT6, SOCS1 and downstream target PIM1 [34,44,48,51,53]. The role of SOCS1 mutations in DLBCL prognosis and relapse has been more complicated to unravel, which relates to the different functions of SOCS1 [111,112], the molecular consequences of the mutations, and their impact on survival $[45,113]$. A recent study showed that SOCS1 pathogenic mutations confer reduced OS in R-CHOP-treated elderly DLBCL patients [114], which fits with the notion that SOCS1 mutations occur more frequently in relapsed DLBCL [34,51,53]. Furthermore, R/R DLBCL-enriched inactivating gene lesions target NFKBIE [34,51], which will lead to NF-kB-mediated production of IL-6 and IL-10 resulting in autocrine signaling and constitutive activation of JAK1/2 and STAT3 [115,116]. Collectively, these findings argue that activated JAK-STAT signaling represents a recurrent driver in relapsed DLBCL.

\subsection{Role of Immune Escape in Relapsed/Refractory DLBCL}

Evasion of immune surveillance is a critical step for DLBCL tumor development and relates to several mechanisms $[117,118]$, some of which are associated with relapsed DLBCL (Figure 2). One immune escape strategy involves a "hide" mechanism by interfering with antigen presentation and impaired T cell recognition [119]. In DLBCL, relapse-enriched mutations have been reported in HLA genes [53], and in CIITA encoding a transactivator of MHC-II gene expression [48]. Furthermore, multiple studies have observed an increased frequency of $B 2 M$ gene alterations or relapse-specific variants, including non-synonymous mutations, frameshift indels, and focal deletions [34,46,51-53]. These inactivating B2M gene lesions impair MHC class I folding and transport to the cell surface, causing loss of (neo-)antigen presentation and thereby allowing immune escape [120]. Alternative mechanisms that contribute to reduced MHC-I protein levels in relapsed disease involve the acquisition of gene mutations targeting (epi-)genetic regulators of MHC-I gene expression, such as EZH2 [121].

Attenuated B2M expression may also hold important consequences for therapies with immune checkpoint inhibitors (ICI), since proper tumor antigen presentation is required for the effective action of ICI. For instance, in melanoma, B2M gene alterations have been linked to ICI resistance [122,123], although in microsatellite instability-high colorectal carcinomas, patients with mutant B2M still benefited from immunotherapy [124]. With $20 \%$ of DLBCL harboring PD-L1 positive lymphomas, the presence of $B 2 M$ alterations may be important in ICI directed against the programmed death 1 (PD-1)/PD ligand 1 (PD-L1) interaction in R/R DLBCL [125,126]. The occurrence of PD-L1 alterations in DLBCL relates to inferior PFS after R-CHOP therapy, although in R/R patients these alterations are associated with anti-PD1 therapy response [127]. Moreover, PD-L1 alterations are linked to impaired antigen presentation and increased T-cell immune surveillance [127].

Interestingly, a lack of B2M and reduced MHC-I expression often co-occurs with loss of CD58 cell surface expression in primary DLBCL [128]. CD58 is a cell adhesion molecule expressed on antigen presenting cells (APCs), including B cells, that activates T cells and NK cells through binding 
to CD2 [129-131]. The absence of CD58 expression may abrogate NK cell killing of B-lymphoma cells that lack MHC-I expression (missing-self recognition), but also impairs ADCC in the context of rituximab treatment. Indeed, genetic inactivation of CD58 in DLBCL cell lines is correlated with decreased NK cell-mediated cytolysis [128] and copy number loss or mutations in CD58 are associated with inferior prognosis in DLBCL [97]. Moreover, gain of CD58 genetic alterations in matched diagnosis-relapse samples has been observed, including relapse-specific deletions and a frameshift indel in CD58 gene [34,46], and CD58 mutations are more prevalent in diagnosis samples of patients with $\mathrm{R} / \mathrm{R}$ disease $[48,54]$. In addition, aberrant CD58 protein expression and epigenetic gene silencing has been observed in DLBCL samples without CD58 genetic lesions, indicating alternative pathways that deregulate CD58 function [128,132].

(a) Functional B2M and CD58 expression

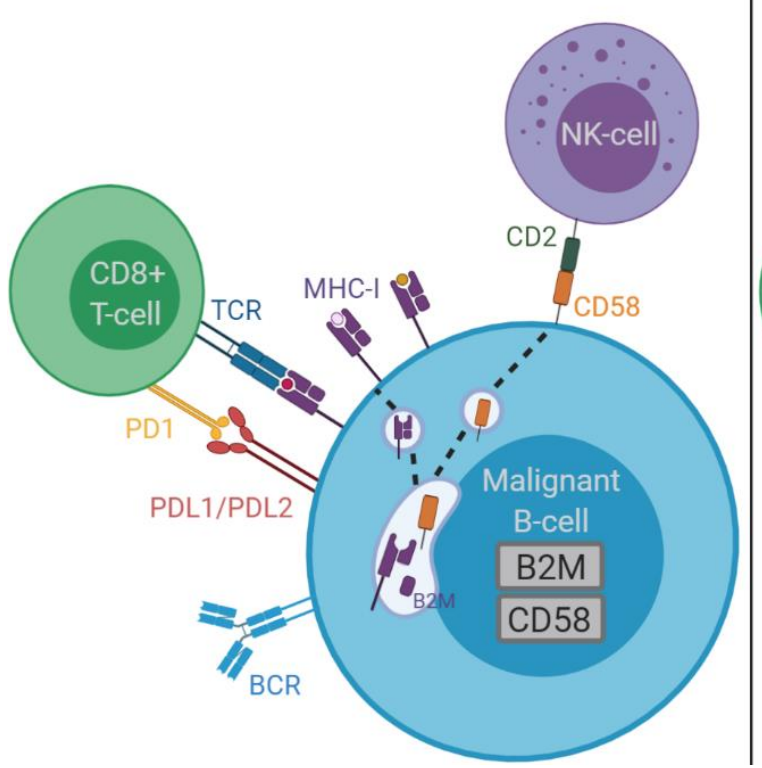

(b) Altered B2M and CD58 expression

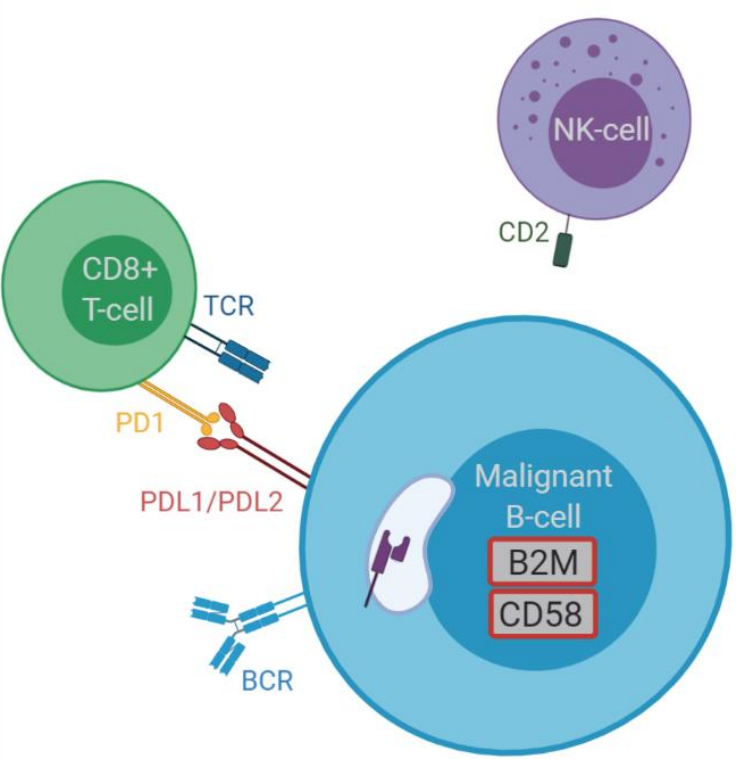

Figure 2. Immune escape strategies in relapsed DLBCL: (a) Malignant B-cell with normal B2M and CD58 expression, where B2M assembles with MHC-I, allowing antigen presentation and recognition by TCR in CD8+ T-cells. CD58 expression facilitates interaction and activation of NK- and T-cells through CD2 binding; (b) Malignant B-cell with inactivating B2M and CD58 mutation or expression show impaired MHC-I cell surface expression, enabling escape from immune surveillance. TCR, T cell receptor; BCR, B cell receptor; NK-cell, natural killer cell; PD-1, programmed cell death 1; PD-L1, programmed cell death 1 ligand 1; PD-L2, programmed cell death 1 ligand 2.

\subsection{Gene Mutations Affecting Epigenetic Regulators in Relapsed/Refractory DLBCL}

Perturbation of epigenetic regulation is a common feature in DLBCL, with frequent gene alterations in histone methyltransferases (HMTs) and histone acetyltransferases (HATs) [133]. These proteins are able to regulate the modification of histones as well as the function of transcription factors, thereby controlling chromatin accessibility and affecting gene expression [134,135]. Interestingly, mutations in several epigenetic regulators, including lysine methyltransferase genes EZH2 and KTM2D, as well as the HAT genes CREBBP and EP300, are clearly linked to R/R DLBCL [34,44-46,51,52].

Lymphoma-associated mutations affecting Polycomb protein EZH2 represent gain-of-function alterations, which enhance EZH2 methyltransferase activity leading to increased H3K27me3 and repression of transcription. EZH2 mutations have been identified as a driver for relapsed DLBCL [52], with increased frequencies in matched diagnosis-relapse analysis [44,51], and independent R/R DLBCL cohorts $[25,34,44]$. KMT2D mutations, which impair KMT2D/MLL2 protein function in mediating H3K4 mono- and di-methylation, have been reported as an early event in lymphoma development $[45,46]$. 
Although allele frequencies of KMT2D mutations are mostly stable between diagnosis and relapse, clonal expansions have been detected in relapsed DLBCL [34,45]. As such, KMT2D mutations have been reported as one of the most frequently observed relapse-associated gene alterations, present in $44 \%$ of relapsed DLBCL [45]. Similarly, loss-of-function KMT2D mutations occur more frequently in R/R DLBCL cohorts as compared to primary DLBCL [34,44,45]. Mutations in the closely related KMT2C gene encoding MLL3 have also been associated with relapse [34,45,51,53], arguing that functional loss of either Trithorax-group protein fulfills an important role in the selective outgrowth of the relapse-initiating clone.

Other gene mutations that are clonally maintained in paired diagnosis-relapse samples involve the HAT genes CREBBP and EP300 [34,44,46], which encode the homologous proteins CBP and p300. Moreover, gain in gene alterations and clonal expansions of $C R E B B P$ and EP300 mutations have been detected [34,44,46,51,52], which are linked to glucocorticoid resistance [136]. Furthermore, CREBBP mutations are present at higher frequency in R/R DLBCL cohorts, compared to primary DLBCL $[34,52]$ Notably, MLL2 and MLL3 act as coactivators at enhancers and prime enhancers for gene activation through the recruitment of CBP and p300, indicating functional interaction between these two different families of histone modifiers [137]. Other regulators of the epigenome that harbor additional SNVs at relapse include TET2 and BRD4 [46]. Together, these data provide strong evidence that dysregulated activity of epigenetic regulators promotes DLBCL relapse.

An interesting observation that links these epigenetic proteins to relapse relates to their ability to functionally regulate key proteins associated with therapy resistance. KMT2D acts as a p53 coactivator as part of the ASCOM complex with ASC2, required for induction of endogenous p53 in response to DNA damage [138]. Furthermore, EZH2 has been linked to decreased CD58 expression in B-cell lymphoma, with high H3K27me3 levels at the CD58 promotor region, and increased CD58 expression upon EZH2 inhibition [132]. Indeed, EZH2 mutations result in global H3K27me3 reprogramming that impacts B cell function and the surrounding immunological niche [139]. In addition, loss of CBP/p300 function leads to impaired acetylation of p53 and BCL6, resulting in decreased p53 activity and constitutive activation of BCL6 [140]. Thus, these epigenetic modulators may impact relapse and therapy resistance by affecting gene regulation and immune responses in both a direct and indirect manner.

\section{Therapies Targeting Relapse-Associated Drivers}

Multiple novel therapeutic agents are being developed to improve DLBCL treatment outcome, several of which target potential drivers of R-CHOP therapy resistance (Figure 3). In-depth discussions of specific treatment strategies for R/R B-cell lymphomas are also described elsewhere [141,142].

\subsection{BCL2 Inhibitors}

The BCL2 inhibitor (BCL2i) venetoclax has shown significant benefical activity in CLL and acute myeloid leukemia (AML) [143-145], but the therapeutic effects in DLBCL are still under investigation. The phase Ib study of venetoclax in combination with immunochemotherapy in R/R NHL patients showed CR in 7 out of 8 DEL patients [146]. The phase II CAVALLI clinical trial demonstrated $80 \%$ PFS in DLBCL patients treated with venetoclax/R-CHOP versus $67 \%$ in the R-CHOP treated cohort, and $78 \%$ PFS versus $61 \%$ in the BCL2 IHC-positive group, with no significant differences in 2-year OS [147]. The therapeutic effect of venetoclax in combination with R-CHOP for DEL patients or DA-EPOCH-R for DHL patients will be revealed in the ongoing phase III trial (NCT03984448). Possible mechanisms for venetoclax resistance is feedback upregulation of MCL1 and BCL- $X_{L}$ expression [148], or the rare event of PMAIP1/NOXA gene amplification [149]. Therefore, the combination of venetoclax with strategies targeting BCL- $\mathrm{X}_{\mathrm{L}}$ and MCL1, such as PI3K delta inhibitor idelalisib, seems to be promising, where synergizing effects have been observed in DLBCL cell lines and in vivo mouse models $[150,151]$. This also holds true for BCL2i combination with the dual-inhibitor of HDACs and PI3K, CUDC-907 
(fimepinostat) [152,153], which is currently under efficiacy and safety evaluation in a phase I clinical trial in R/R DLBCL (NCT01742988).

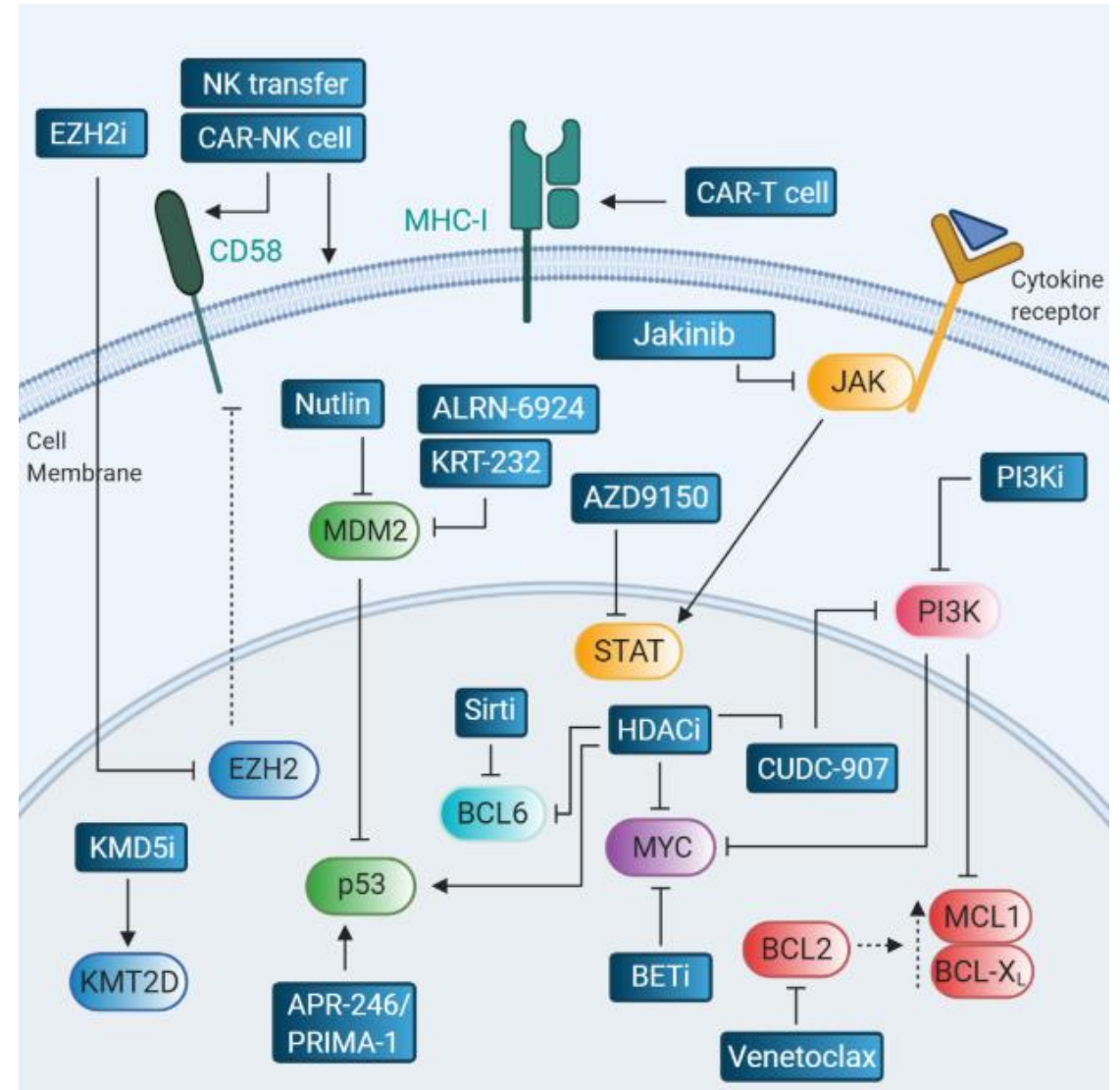

Figure 3. Therapeutic modalities targeting relapse-associated drivers. EZH2i, EZH2 inhibitors; NK, natural killer cell; CAR-NK cell, chimeric antigen receptor-NK cell; CAR-T cell, chimeric antigen receptor-T cell; KMD5i, KMD5 inhibitor; HDACi, histone deacetylase inhibitor; BETi, BET inhibitor; PI3Ki, PI3K inhibitor; Sirti, sirtuin inhibitor.

\subsection{MYC Inhibitors}

Given the essential role of MYC in DLBCL/HGBL pathogenesis and its association with relapse, different therapeutic strategies are being developed to target MYC-dependent lymphomas [153]. One approach involves interference with MYC-mediated transcription using inhibitors directed against BET bromodomain-containing proteins [154,155], which serve as organizers of the transcriptional machinery [156]. Phase I/II clinical trials are ongoing with different BET inhibitors, including JQ1 derivative GSK525762 (NCT01943851), and CPI-0610 (NCT01949883). Secondly, there are several strategies that target MYC protein through PI3K inhibition, which also shows therapeutic effects in the context of enhanced BCL2 activity. As such, the PI3K delta inhibitor, idelalisib, which affects MYC protein stability [157], is currently being investigated in a phase II clinical trial for R/R DLBCL (NCT03576443), although preliminary data show only limited response rates [158]. However, the dual PI3K HDAC inhibitor CUDC-907 showed promising results in a phase I study in R/R DLBCL patients harboring MYC translocation or amplification [159], and is currently being evaluated in a phase II clinical trial (NCT02674750). Notably, several studies have assessed the combinatorial effects of both BCL2 and MYC targeting, exploiting venetoclax with CUDC-907, BETi (NCT03255096) or PI3K inhibitor (NCT03886649, NCT04572763). Further elaboration of these synergizing effects may result in better treatment of BCL2- and MYC-positive DLBCL [152,154,160]. 


\subsection{Targeting the p53 Pathway}

There are several therapeutic strategies to target attenuated p53 activity in cancer, some of which may become beneficial for DLBCL patients harboring TP53 mutations. One approach is to restore wild-type p53 function in tumor cells through structural reactivation of mutant p53 with small peptides, among which are PRIMA-1 and APR-246 (NCT04419389), as well as strategies targeting the MDM2/MDM4-p53 axis [161-163]. Nutlins are non-peptide small molecules that bind to the p53 binding groove in MDM2 hereby preventing degradation of p53 [164]. Administration of nutlin-3a in IGH-BCL2 and TP53-mutant DLBCL cells, has been shown to enhance the cytotoxic effect of doxorubicin [165]. However, the activity of nutlins is compromised by other p53-pathway aberrations, such as MDM4 overexpression, and may lead to overexpression of mutant p53 [95]. A novel MDM2 inhibitor that will be in clinical trial for R/R DLBCL patients in combination with a BTK inhibitor, is KRT-232 (NCT04502394). Progress has also been made in the development of stapled peptides, such as ALRN-6924, that inhibit both MDM2-p53 and MDM4-p53 interaction, which are under (pre-)clinical evaluation for hematological malignancies (NCT02264613) [166,167]. Other candidate therapeutic approaches involve the targeting of DNA damage and cell cycle checkpoints through pharmacologic inhibition of ATM/ATR or CHK1/2 kinases, and immunotherapy with bispecific T-cell engaging (BiTE) antibody recognizing mutant p53 peptides [168].

\subsection{Targeting the JAK/STAT Pathway}

Multiple JAK inhibitors (jakinibs) have been developed, which inhibit one or multiple JAK proteins, hereby interfering with upstream JAK-STAT signaling leading to reduced cell survival [169]. Beneficial effects of these inhibitors have been observed in leukemia and lymphoma cell line and animal studies, and some strategies are currently being employed in clinical studies [170]. In R/R DLBCL a phase II trial is ongoing assessing ruxolitinib in R/R DLBCL (NCT01431209), and synergizing effects are evaluated in the combination of JAK1 inhibitor, itacitinib, with ibrutinib (NCT02760485). Additionally, the combination of itacitinib with PI3Kdelta inhibitor has been assessed in a phase I trial with R/R B-cell lymphomas [171] (NCT01905813). Although more limited than JAK inhibitors, there are some strategies to target STAT proteins, which are under clinical investigation [172]. As such, STAT3 inhibitor AZD9150 is being clinically evaluated in R/R DLBCL (NTC03527147). Other suggested strategies involve the indirect inhibition of STAT proteins through the modulation of biological STAT inhibitors, such as the SOCS and PIAS families [173].

\subsection{Therapeutic Strategies in the Context of Immune Escape}

As immune escape is observed in both diagnosis and relapsed DLBCL, it is important to develop therapy strategies that overcome this critical issue. The DLBCL associated (epi-)genetic alterations in CD58 and B2M result in loss-of-function, allowing lymphoma cells to escape immune responses. For reversing epigenetic silencing of CD58 expression, EZH2 inhibitors have been shown to be effective [132]. A proposed strategy for rescuing defective B2M expression involves administration of an adenoviral vector expressing B2M, which in tumor cell lines has been shown to recover MHC-I expression, and tumor cell destruction by CD8+ T-cells [174]. However, alternative, more realistic approaches for DLBCL patients with defective antigen presentation represent cellular immunotherapies, including chimeric antigen receptor (CAR) T cell therapy directed against tumor cell surface antigens, such as CD19 and CD79 [142]. These immunotherapies are effective without the requirement of antigen presentation. At present, two different CD19-directed CAR T cell products have been approved for treatment of R/R DLBCL after two lines of systemic therapy, namely axicabtagene ciloleucel (Axi-cel; Yescarta) (NCT03391466, NCT03761056, NCT04002401), and tisagenlecleucel (CTL109; Kymriah) (NCT03642626) [175,176]. Other forms of cellular immunotherapy include adoptive transfer of NK cells and CAR NK cell targeting that could have potential for R/R DLBCL, including patients with diminished CD58 levels [177]. For ICI therapy, limited beneficial effects of nivolumab alone [178] 
and the combination of durvalumab with ibrutinib [179] have been reported. However, ongoing studies should reveal the efficacy of ICI- nivolumab (NCT03704714, NCT03749018), pembrolizumab (NCT03990961, NCT03401853), and durvalumab (NCT03003520)- in several combination therapies for $\mathrm{R} / \mathrm{R}$ DLBCL, and establish the predictive value of $B 2 M$ mutations in these patients.

\subsection{Epigenetic Targeting}

In the past decade, different epigenetic therapies have been explored in cancer treatment, and several HDAC targeting drugs are now FDA approved for various hematological malignancies [180]. HDAC inhibitors (HDACi) are candidate drugs to treat DLBCL patients with elevated MYC in combination with enhanced BCL2 levels, thereby deregulating MYC expression and activity [181-183]. HDACi also promote the accumulation of acetylated BCL6, which inhibits the ability of BCL6 to recruit co-repressors required for transcription regulation, eventually leading to cell cycle arrest and apoptosis in BCL6-positive (GCB-)DLBCL [184]. However, the clinical therapeutic efficacy of HDACi vorinostat and panobinostat have been reported to be limited in relapsed DLBCL $[185,186]$, although HDACi abexinostat seems to be more promising [187]. Small inhibitory molecules against another class of histone deacetylases, Sirtuins, may also repress (GCB-)DLBCL growth through inhibition of BCL6 function [188]. An additional benefit of deacteylase inhibitors relates to increased levels of acetylated (wild-type) p53, which strongly stimulates its pro-apoptotic activity [189].

Specific therapeutic targeting of epigenetic modifiers has emerged for chromatin reader protein BRD4 for MYC-dependent DLBCL (BET-domain inhibitors) [154], and EZH2 for mainly GCB-type DLBCL [190]. Selective EZH2 inhibition leads to growth inhibition, differentiation and apoptosis of DLBCL cells with activating EZH2 mutations [191,192]. The development of EZH2 inhibitor tazemetostat as monotherapy or in combination with prednisolone has been stalled (NCT01897571), but is under study in combination with atezolizumab in R/R DLBCL (NCT02220842), and R-CHOP as a first-line treatment for newly diagnosed DLBCL patients (NCT02889523). Most other genetic alterations affecting epigenetic modifiers represent loss-of-function mutations, and therapeutic targeting of these pathways is more challenging. In case of inactivating KMT2D gene lesions, inhibition of KMD5/JARID1 has been proposed, which is known to counteract KTM2D by demethylating H3K4me3/2, and has been linked to cancer chemoresistance [193]. Indeed, KMD5 inhibition leads to increased H3K4me3 levels showing strong anti-proliferative and cytotoxic effects in KMT2D mutant GCB-DLBCL cell lines with concomitant diminished BCR signaling and altered expression of BCL2 family members [194]. Thus, epigenetic targeting represents an interesting tool to counteract specific gene lesions associated with relapse and therapy resistance.

\section{Conclusions and Future Directions}

Despite the development of many novel therapeutic modalities for DLBCL treatment, R-CHOP still represents the choice of first-line therapy for most DLBCL patients. However, resistance to $\mathrm{R}-\mathrm{CHOP}$ remains a persistent problem, with knowledge still limited regarding the genetic alterations that drive immunotherapy resistance, resulting in the outgrowth of the relapse-initiating clone towards a full-blown relapse. In the past years, studies investigating the mutational landscape of R/R DLBCL have improved our insight on this topic. In line with the heterogeneity of the disease, the identified genes that represent relapse-enriched mutations show variability between the different studies outside the common targets described in this review. Part of this variation can be explained by the relatively small cohorts and the different sequencing platforms in these studies. Nevertheless, many of the identified genes can be assigned to specific pathways and biological functions, thereby revealing important mechanisms that define candidate R-CHOP immunochemotherapy resistance genes.

Not surprisingly, many of the recurrent genes are linked to the regulation of apoptosis and cell proliferation, including BCL2 anti-apoptotic family members, MYC and p53, which highlights the importance for the therapeutic targeting of these proteins and associated pathways. However, there is limited evidence for beneficial effects of targeting these pathways by single targeting agents. For this 
reason, combinations of targeted therapies, such as inhibitors that may target multiple anti-apoptotic BCL2 family members, combined with drugs that affect MYC, p53 pathway, immune escape genes and/or epigenetic regulators may lead to synergizing effects and could be beneficial for R/R DLBCL patients. It is evident that (epi-)genetic alterations in these candidate R-CHOP resistance drivers are not shared by all relapsed tumors, implying that there is redundancy with other gene mutations that confer therapy resistance. The identification of these genetic relapse drivers will be essential to develop targeted therapies for this group of relapse-prone DLBCL patients. Hence, more extensive NGS analysis of paired diagnosis-relapse cohorts will be required to identify the remaining class of less prevalent relapse-enriched gene aberrations. Ideally in future routine diagnostics, the presence of these genetic alterations could be used as a diagnostic biomarker for immunochemotherapy resistance, and in this way guide alternative treatment choices.

Author Contributions: Conceptualization, M.R.B. and B.S.; methodology, M.R.B. and B.S.; literature search, M.R.B. and B.S.; writing - original draft preparation, M.R.B. and B.S.; writing-review and editing, M.R.B., W.B.C.S., M.v.d.B., J.H.v.K. and B.S.; visualization, M.R.B.; supervision, B.S.; funding acquisition, J.H.v.K. and B.S. All authors have read and agreed to the published version of the manuscript.

Funding: This research was funded by the Dutch Cancer Society (KWF Kankerbestrijding), grant number 11137.

Acknowledgments: All figures were created with BioRender.com.

Conflicts of Interest: The authors declare no conflict of interest.

\section{References}

1. Li, S.; Young, K.H.; Medeiros, L.J. Diffuse large B-cell lymphoma. Pathology 2018, 50, 74-87. [CrossRef]

2. Martelli, M.; Ferreri, A.J.; Agostinelli, C.; Di Rocco, A.; Pfreundschuh, M.; Pileri, S.A. Diffuse large B-cell lymphoma. Crit. Rev. Oncol. Hematol. 2013, 87, 146-171. [CrossRef] [PubMed]

3. Lossos, I.S.; Gascoyne, R.D. Transformation of follicular lymphoma. Best Pract. Res. Clin. Haematol. 2011, 24, 147-163. [CrossRef] [PubMed]

4. Møller, M.B.; Pedersen, N.T.; Christensen, B.E. Diffuse large B-cell lymphoma: Clinical implications of extranodal versus nodal presentation-A population-based study of 1575 cases. Br. J. Haematol. 2004, 124, 151-159. [CrossRef] [PubMed]

5. Coiffier, B.; Thieblemont, C.; Van Den Neste, E.; Lepeu, G.; Plantier, I.; Castaigne, S.; Lefort, S.; Marit, G.; Macro, M.; Sebban, C.; et al. Long-term outcome of patients in the LNH-98.5 trial, the first randomized study comparing rituximab-CHOP to standard CHOP chemotherapy in DLBCL patients: A study by the Groupe d'Etudes des Lymphomes de l'Adulte. Blood 2010, 116, 2040-2045. [CrossRef] [PubMed]

6. Fu, K.; Weisenburger, D.D.; Choi, W.W.; Perry, K.D.; Smith, L.M.; Shi, X.; Hans, C.P.; Greiner, T.C.; Bierman, P.J.; Bociek, R.G.; et al. Addition of rituximab to standard chemotherapy improves the survival of both the germinal center B-cell-like and non-germinal center B-cell-like subtypes of diffuse large B-cell lymphoma. J. Clin. Oncol. 2008, 26, 4587-4594. [CrossRef] [PubMed]

7. Poeschel, V.; Held, G.; Ziepert, M.; Witzens-Harig, M.; Holte, H.; Thurner, L.; Borchmann, P.; Viardot, A.; Soekler, M.; Keller, U.; et al. Four versus six cycles of CHOP chemotherapy in combination with six applications of rituximab in patients with aggressive B-cell lymphoma with favourable prognosis (FLYER): A randomised, phase 3, non-inferiority trial. Lancet 2019, 394, 2271-2281. [CrossRef]

8. Maurer, M.J.; Ghesquières, H.; Jais, J.P.; Witzig, T.E.; Haioun, C.; Thompson, C.A.; Delarue, R.; Micallef, I.N.; Peyrade, F.; Macon, W.R.; et al. Event-free survival at 24 months is a robust end point for disease-related outcome in diffuse large B-cell lymphoma treated with immunochemotherapy. J. Clin. Oncol. 2014, 32, 1066-1073. [CrossRef]

9. Larouche, J.F.; Berger, F.; Chassagne-Clément, C.; Ffrench, M.; Callet-Bauchu, E.; Sebban, C.; Ghesquières, H.; Broussais-Guillaumot, F.; Salles, G.; Coiffier, B. Lymphoma recurrence 5 years or later following diffuse large B-cell lymphoma: Clinical characteristics and outcome. J. Clin. Oncol. 2010, 28, 2094-2100. [CrossRef]

10. Stephens, D.M.; Li, H.; LeBlanc, M.L.; Puvvada, S.D.; Persky, D.; Friedberg, J.W.; Smith, S.M. Continued Risk of Relapse Independent of Treatment Modality in Limited-Stage Diffuse Large B-Cell Lymphoma: Final and Long-Term Analysis of Southwest Oncology Group Study S8736. J. Clin. Oncol. 2016, 34, 2997-3004. [CrossRef] 
11. Wang, Y.; Farooq, U.; Link, B.K.; Larson, M.C.; King, R.L.; Maurer, M.J.; Allmer, C.; Hefazi, M.; Thompson, C.A.; Micallef, I.N.; et al. Late Relapses in Patients With Diffuse Large B-Cell Lymphoma Treated with Immunochemotherapy. J. Clin. Oncol. 2019, 37, 1819-1827. [CrossRef] [PubMed]

12. Bobillo, S.; Joffe, E.; Lavery, J.A.; Sermer, D.; Ghione, P.; Noy, A.; Caron, P.C.; Hamilton, A.M.; Hamlin, P.A.; Horwitz, S.M.; et al. Clinical Characteristics and Outcomes of Extranodal Stage I Diffuse Large B Cell Lymphoma in The Rituximab-Era. Blood 2020. [CrossRef] [PubMed]

13. Alizadeh, A.A.; Eisen, M.B.; Davis, R.E.; Ma, C.; Lossos, I.S.; Rosenwald, A.; Boldrick, J.C.; Sabet, H.; Tran, T.; $\mathrm{Yu}, \mathrm{X} . ;$ et al. Distinct types of diffuse large B-cell lymphoma identified by gene expression profiling. Nature 2000, 403, 503-511. [CrossRef] [PubMed]

14. Rosenwald, A.; Wright, G.; Chan, W.C.; Connors, J.M.; Campo, E.; Fisher, R.I.; Gascoyne, R.D.; Muller-Hermelink, H.K.; Smeland, E.B.; Giltnane, J.M.; et al. The use of molecular profiling to predict survival after chemotherapy for diffuse large-B-cell lymphoma. N. Engl. J. Med. 2002, 346, 1937-1947. [CrossRef] [PubMed]

15. Scott, D.W.; Wright, G.W.; Williams, P.M.; Lih, C.J.; Walsh, W.; Jaffe, E.S.; Rosenwald, A.; Campo, E.; Chan, W.C.; Connors, J.M.; et al. Determining cell-of-origin subtypes of diffuse large B-cell lymphoma using gene expression in formalin-fixed paraffin-embedded tissue. Blood 2014, 123, 1214-1217. [CrossRef]

16. Jais, J.P.; Molina, T.J.; Ruminy, P.; Gentien, D.; Reyes, C.; Scott, D.W.; Rimsza, L.M.; Wright, G.; Gascoyne, R.D.; Staudt, L.M.; et al. Reliable subtype classification of diffuse large B-cell lymphoma samples from GELA LNH2003 trials using the Lymph2Cx gene expression assay. Haematologica 2017, 102, e404-e406. [CrossRef]

17. Davis, R.E.; Ngo, V.N.; Lenz, G.; Tolar, P.; Young, R.M.; Romesser, P.B.; Kohlhammer, H.; Lamy, L.; Zhao, H.; Yang, Y. Chronic active B-cell-receptor signalling in diffuse large B-cell lymphoma. Nature 2010, 463, 88-92. [CrossRef]

18. Sehn, L.H.; Gascoyne, R.D. Diffuse large B-cell lymphoma: Optimizing outcome in the context of clinical and biologic heterogeneity. Blood 2015, 125, 22-32. [CrossRef]

19. Quintanilla-Martinez, L. The 2016 updated WHO classification of lymphoid neoplasias. Hematol. Oncol. 2017, 35 (Suppl. 1), 37-45. [CrossRef]

20. Rosenthal, A.; Younes, A. High grade B-cell lymphoma with rearrangements of MYC and BCL2 and/or BCL6: Double hit and triple hit lymphomas and double expressing lymphoma. Blood Rev. 2017, 31, 37-42. [CrossRef]

21. Sesques, P.; Johnson, N.A. Approach to the diagnosis and treatment of high-grade B-cell lymphomas with MYC and BCL2 and/or BCL6 rearrangements. Blood 2017, 129, 280-288. [CrossRef] [PubMed]

22. Sarkozy, C.; Traverse-Glehen, A.; Coiffier, B. Double-hit and double-protein-expression lymphomas: Aggressive and refractory lymphomas. Lancet Oncol. 2015, 16, e555-e567. [CrossRef]

23. Ennishi, D.; Jiang, A.; Boyle, M.; Collinge, B.; Grande, B.M.; Ben-Neriah, S.; Rushton, C.; Tang, J.; Thomas, N.; Slack, G.W.; et al. Double-Hit Gene Expression Signature Defines a Distinct Subgroup of Germinal Center B-Cell-Like Diffuse Large B-Cell Lymphoma. J. Clin. Oncol. 2019, 37, 190-201. [CrossRef] [PubMed]

24. Schmitz, R.; Wright, G.W.; Huang, D.W.; Johnson, C.A.; Phelan, J.D.; Wang, J.Q.; Roulland, S.; Kasbekar, M.; Young, R.M.; Shaffer, A.L.; et al. Genetics and Pathogenesis of Diffuse Large B-Cell Lymphoma. N. Engl. J. Med. 2018, 378, 1396-1407. [CrossRef] [PubMed]

25. Chapuy, B.; Stewart, C.; Dunford, A.J.; Kim, J.; Kamburov, A.; Redd, R.A.; Lawrence, M.S.; Roemer, M.G.M.; Li, A.J.; Ziepert, M.; et al. Molecular subtypes of diffuse large B cell lymphoma are associated with distinct pathogenic mechanisms and outcomes. Nat. Med. 2018, 24, 679-690. [CrossRef]

26. Wright, G.W.; Huang, D.W.; Phelan, J.D.; Coulibaly, Z.A.; Roulland, S.; Young, R.M.; Wang, J.Q.; Schmitz, R.; Morin, R.D.; Tang, J.; et al. A Probabilistic Classification Tool for Genetic Subtypes of Diffuse Large B Cell Lymphoma with Therapeutic Implications. Cancer Cell 2020, 37, 551-568.e514. [CrossRef]

27. Lacy, S.E.; Barrans, S.L.; Beer, P.A.; Painter, D.; Smith, A.G.; Roman, E.; Cooke, S.L.; Ruiz, C.; Glover, P.; Van Hoppe, S.J.L.; et al. Targeted sequencing in DLBCL, molecular subtypes, and outcomes: A Haematological Malignancy Research Network report. Blood 2020, 135, 1759-1771. [CrossRef]

28. Housman, G.; Byler, S.; Heerboth, S.; Lapinska, K.; Longacre, M.; Snyder, N.; Sarkar, S. Drug resistance in cancer: An overview. Cancers 2014, 6, 1769-1792. [CrossRef]

29. Scheijen, B. Molecular mechanisms contributing to glucocorticoid resistance in lymphoid malignancies. Cancer Drug Resist. 2019, 2, 647-664. [CrossRef] 
30. Maloney, D.G.; Smith, B.; Rose, A. Rituximab: Mechanism of action and resistance. Semin Oncol. 2002, 29, 2-9. [CrossRef]

31. Bonavida, B. 'Rituximab-induced inhibition of antiapoptotic cell survival pathways: Implications in chemo/immunoresistance, rituximab unresponsiveness, prognostic and novel therapeutic interventions'. Oncogene 2007, 26, 3629-3636. [CrossRef] [PubMed]

32. Pescovitz, M.D. Rituximab, an anti-cd20 monoclonal antibody: History and mechanism of action. Am. J. Transpl. 2006, 6, 859-866. [CrossRef] [PubMed]

33. Jazirehi, A.R.; Bonavida, B. Cellular and molecular signal transduction pathways modulated by rituximab (rituxan, anti-CD20 mAb) in non-Hodgkin's lymphoma: Implications in chemosensitization and therapeutic intervention. Oncogene 2005, 24, 2121-2143. [CrossRef] [PubMed]

34. Rushton, C.K.; Arthur, S.E.; Alcaide, M.; Cheung, M.; Jiang, A.; Coyle, K.M.; Cleary, K.L.S.; Thomas, N.; Hilton, L.K.; Michaud, N.; et al. Genetic and evolutionary patterns of treatment resistance in relapsed B-cell lymphoma. Blood Adv. 2020, 4, 2886-2898. [CrossRef] [PubMed]

35. Tomita, A. Genetic and Epigenetic Modulation of CD20 Expression in B-Cell Malignancies: Molecular Mechanisms and Significance to Rituximab Resistance. J. Clin. Exp. Hematop. 2016, 56, 89-99. [CrossRef]

36. Thomsen, E.A.; Rovsing, A.B.; Anderson, M.V.; Due, H.; Huang, J.; Luo, Y.; Dybkaer, K.; Mikkelsen, J.G. Identification of BLNK and BTK as mediators of rituximab-induced programmed cell death by CRISPR screens in GCB-subtype diffuse large B-cell lymphoma. Mol. Oncol. 2020, 14, 1978-1997. [CrossRef]

37. Kuiper, R.P.; Waanders, E.; van der Velden, V.H.; van Reijmersdal, S.V.; Venkatachalam, R.; Scheijen, B.; Sonneveld, E.; van Dongen, J.J.; Veerman, A.J.; van Leeuwen, F.N.; et al. IKZF1 deletions predict relapse in uniformly treated pediatric precursor B-ALL. Leukemia 2010, 24, 1258-1264. [CrossRef]

38. Mullighan, C.G.; Su, X.; Zhang, J.; Radtke, I.; Phillips, L.A.; Miller, C.B.; Ma, J.; Liu, W.; Cheng, C.; Schulman, B.A.; et al. Deletion of IKZF1 and prognosis in acute lymphoblastic leukemia. N. Engl. J. Med. 2009, 360, 470-480. [CrossRef]

39. Landau, D.A.; Tausch, E.; Taylor-Weiner, A.N.; Stewart, C.; Reiter, J.G.; Bahlo, J.; Kluth, S.; Bozic, I.; Lawrence, M.; Bottcher, S.; et al. Mutations driving CLL and their evolution in progression and relapse. Nature 2015, 526, 525-530. [CrossRef]

40. Rossi, D.; Cerri, M.; Deambrogi, C.; Sozzi, E.; Cresta, S.; Rasi, S.; De Paoli, L.; Spina, V.; Gattei, V.; Capello, D.; et al. The prognostic value of TP53 mutations in chronic lymphocytic leukemia is independent of Del17p13: Implications for overall survival and chemorefractoriness. Clin. Cancer Res. 2009, 15, 995-1004. [CrossRef]

41. Rossi, D.; Khiabanian, H.; Spina, V.; Ciardullo, C.; Bruscaggin, A.; Fama, R.; Rasi, S.; Monti, S.; Deambrogi, C.; De Paoli, L.; et al. Clinical impact of small TP53 mutated subclones in chronic lymphocytic leukemia. Blood 2014, 123, 2139-2147. [CrossRef] [PubMed]

42. Campo, E.; Cymbalista, F.; Ghia, P.; Jäger, U.; Pospisilova, S.; Rosenquist, R.; Schuh, A.; Stilgenbauer, S. TP53 aberrations in chronic lymphocytic leukemia: An overview of the clinical implications of improved diagnostics. Haematologica 2018, 103, 1956-1968. [CrossRef] [PubMed]

43. Aitken, M.J.L.; Lee, H.J.; Post, S.M. Emerging treatment options for patients with p53-pathway-deficient CLL. Ther. Adv. Hematol. 2019, 10. [CrossRef] [PubMed]

44. Melchardt, T.; Hufnagl, C.; Weinstock, D.M.; Kopp, N.; Neureiter, D.; Trankenschuh, W.; Hackl, H.; Weiss, L.; Rinnerthaler, G.; Hartmann, T.N.; et al. Clonal evolution in relapsed and refractory diffuse large B-cell lymphoma is characterized by high dynamics of subclones. Oncotarget 2016, 7, 51494-51502. [CrossRef]

45. Juskevicius, D.; Lorber, T.; Gsponer, J.; Perrina, V.; Ruiz, C.; Stenner-Liewen, F.; Dirnhofer, S.; Tzankov, A. Distinct genetic evolution patterns of relapsing diffuse large B-cell lymphoma revealed by genome-wide copy number aberration and targeted sequencing analysis. Leukemia 2016, 30, 2385-2395. [CrossRef]

46. Jiang, Y.; Redmond, D.; Nie, K.; Eng, K.W.; Clozel, T.; Martin, P.; Tan, L.H.; Melnick, A.M.; Tam, W.; Elemento, $\mathrm{O}$. Deep sequencing reveals clonal evolution patterns and mutation events associated with relapse in B-cell lymphomas. Genome Biol. 2014, 15, 432. [CrossRef]

47. Juskevicius, D.; Dirnhofer, S.; Tzankov, A. Genetic background and evolution of relapses in aggressive B-cell lymphomas. Haematologica 2017, 102, 1139-1149. [CrossRef]

48. Isaev, K.; Ennishi, D.; Hilton, L.; Skinnider, B.; Mungall, K.L.; Mungall, A.J.; Bakhtiari, M.; Tremblay-LeMay, R.; Silva, A.; Ben-Neriah, S.; et al. Molecular Attributes Underlying Central Nervous System and Systemic Relapse in Diffuse Large B-cell Lymphoma. Haematologica 2020. [CrossRef] 
49. Waanders, E.; Gu, Z.; Dobson, S.M.; Antić, Ž.; Crawford, J.C.; Ma, X.; Edmonson, M.N.; Payne-Turner, D.; van der Vorst, M.; Jongmans, M.C.J.; et al. Mutational landscape and patterns of clonal evolution in relapsed pediatric acute lymphoblastic leukemia. Blood Cancer Discov. 2020, 1, 96-111. [CrossRef]

50. Yu, S.L.; Zhang, H.; Ho, B.C.; Yu, C.H.; Chang, C.C.; Hsu, Y.C.; Ni, Y.L.; Lin, K.H.; Jou, S.T.; Lu, M.Y.; et al. FPGS relapse-specific mutations in relapsed childhood acute lymphoblastic leukemia. Sci. Rep. 2020, 10, 12074. [CrossRef]

51. Morin, R.D.; Assouline, S.; Alcaide, M.; Mohajeri, A.; Johnston, R.L.; Chong, L.; Grewal, J.; Yu, S.; Fornika, D.; Bushell, K.; et al. Genetic Landscapes of Relapsed and Refractory Diffuse Large B-Cell Lymphomas. Clin. Cancer Res. 2016, 22, 2290-2300. [CrossRef] [PubMed]

52. Greenawalt, D.M.; Liang, W.S.; Saif, S.; Johnson, J.; Todorov, P.; Dulak, A.; Enriquez, D.; Halperin, R.; Ahmed, A.; Saveliev, V.; et al. Comparative analysis of primary versus relapse/refractory DLBCL identifies shifts in mutation spectrum. Oncotarget 2017, 8, 99237-99244. [CrossRef] [PubMed]

53. Nijland, M.; Seitz, A.; Terpstra, M.; van Imhoff, G.W.; Kluin, P.M.; van Meerten, T.; Atayar, C.; van Kempen, L.C.; Diepstra, A.; Kok, K.; et al. Mutational Evolution in Relapsed Diffuse Large B-Cell Lymphoma. Cancers (Basel) 2018, 10, 459. [CrossRef] [PubMed]

54. Mareschal, S.; Dubois, S.; Viailly, P.J.; Bertrand, P.; Bohers, E.; Maingonnat, C.; Jais, J.P.; Tesson, B.; Ruminy, P.; Peyrouze, P.; et al. Whole exome sequencing of relapsed/refractory patients expands the repertoire of somatic mutations in diffuse large B-cell lymphoma. Genes Chromosomes Cancer 2016, 55, 251-267. [CrossRef]

55. Park, H.Y.; Lee, S.B.; Yoo, H.Y.; Kim, S.J.; Kim, W.S.; Kim, J.I.; Ko, Y.H. Whole-exome and transcriptome sequencing of refractory diffuse large B-cell lymphoma. Oncotarget 2016, 7, 86433-86445. [CrossRef]

56. Peroja, P.; Pedersen, M.; Mantere, T.; Norgaard, P.; Peltonen, J.; Haapasaari, K.M.; Bohm, J.; Jantunen, E.; Turpeenniemi-Hujanen, T.; Rapakko, K.; et al. Mutation of TP53, translocation analysis and immunohistochemical expression of MYC, BCL-2 and BCL-6 in patients with DLBCL treated with R-CHOP. Sci. Rep. 2018, 8, 14814. [CrossRef]

57. Johnson, N.A.; Slack, G.W.; Savage, K.J.; Connors, J.M.; Ben-Neriah, S.; Rogic, S.; Scott, D.W.; Tan, K.L.; Steidl, C.; Sehn, L.H.; et al. Concurrent expression of MYC and BCL2 in diffuse large B-cell lymphoma treated with rituximab plus cyclophosphamide, doxorubicin, vincristine, and prednisone. J. Clin. Oncol. 2012, 30, 3452-3459. [CrossRef]

58. Green, T.M.; Young, K.H.; Visco, C.; Xu-Monette, Z.Y.; Orazi, A.; Go, R.S.; Nielsen, O.; Gadeberg, O.V.; Mourits-Andersen, T.; Frederiksen, M.; et al. Immunohistochemical double-hit score is a strong predictor of outcome in patients with diffuse large B-cell lymphoma treated with rituximab plus cyclophosphamide, doxorubicin, vincristine, and prednisone. J. Clin. Oncol. 2012, 30, 3460-3467. [CrossRef]

59. Miura, K.; Takahashi, H.; Nakagawa, M.; Izu, A.; Sugitani, M.; Kurita, D.; Sakagami, M.; Ohtake, S.; Uchino, Y.; Hojo, A.; et al. Clinical significance of co-expression of MYC and BCL2 protein in aggressive B-cell lymphomas treated with a second line immunochemotherapy. Leuk Lymphoma 2016, 57, 1335-1341. [CrossRef]

60. Herrera, A.F.; Mei, M.; Low, L.; Kim, H.T.; Griffin, G.K.; Song, J.Y.; Merryman, R.W.; Bedell, V.; Pak, C.; Sun, H.; et al. Relapsed or Refractory Double-Expressor and Double-Hit Lymphomas Have Inferior Progression-Free Survival After Autologous Stem-Cell Transplantation. J. Clin. Oncol. 2017, 35, 24-31. [CrossRef]

61. Cuccuini, W.; Briere, J.; Mounier, N.; Voelker, H.U.; Rosenwald, A.; Sundstrom, C.; Cogliatti, S.; Hirchaud, E.; Ysebaert, L.; Bron, D.; et al. MYC+ diffuse large B-cell lymphoma is not salvaged by classical R-ICE or R-DHAP followed by BEAM plus autologous stem cell transplantation. Blood 2012, 119, 4619-4624. [CrossRef] [PubMed]

62. Vaux, D.L.; Cory, S.; Adams, J.M. Bcl-2 gene promotes haemopoietic cell survival and cooperates with c-myc to immortalize pre-B cells. Nature 1988, 335, 440-442. [CrossRef] [PubMed]

63. Adams, C.M.; Clark-Garvey, S.; Porcu, P.; Eischen, C.M. Targeting the Bcl-2 Family in B Cell Lymphoma. Front. Oncol. 2018, 8, 636. [CrossRef] [PubMed]

64. Visco, C.; Tzankov, A.; Xu-Monette, Z.Y.; Miranda, R.N.; Tai, Y.C.; Li, Y.; Liu, W.M.; d'Amore, E.S.; Li, Y.; Montes-Moreno, S.; et al. Patients with diffuse large B-cell lymphoma of germinal center origin with BCL2 translocations have poor outcome, irrespective of MYC status: A report from an International DLBCL rituximab-CHOP Consortium Program Study. Haematologica 2013, 98, 255-263. [CrossRef] 
65. Li, L.; Li, Y.; Que, X.; Gao, X.; Gao, Q.; Yu, M.; Ma, K.; Xi, Y.; Wang, T. Prognostic significances of overexpression MYC and/or BCL2 in R-CHOP-treated diffuse large B-cell lymphoma: A Systematic review and meta-analysis. Sci. Rep. 2018, 8, 6267. [CrossRef]

66. Tsujimoto, Y.; Finger, L.R.; Yunis, J.; Nowell, P.C.; Croce, C.M. Cloning of the chromosome breakpoint of neoplastic B cells with the $\mathrm{t}(14 ; 18)$ chromosome translocation. Science 1984, 226, 1097-1099. [CrossRef]

67. Barrans, S.L.; Evans, P.A.; O'Connor, S.J.; Kendall, S.J.; Owen, R.G.; Haynes, A.P.; Morgan, G.J.; Jack, A.S. The $t(14 ; 18)$ is associated with germinal center-derived diffuse large B-cell lymphoma and is a strong predictor of outcome. Clin. Cancer Res. 2003, 9, 2133-2139.

68. Jost, P.J.; Ruland, J. Aberrant NF-kappaB signaling in lymphoma: Mechanisms, consequences, and therapeutic implications. Blood 2007, 109, 2700-2707. [CrossRef]

69. García-Aranda, M.; Pérez-Ruiz, E.; Redondo, M. Bcl-2 Inhibition to Overcome Resistance to Chemo- and Immunotherapy. Int. J. Mol. Sci. 2018, 19, 3950. [CrossRef]

70. Khan, N.; Kahl, B. Targeting BCL-2 in Hematologic Malignancies. Target Oncol. 2018, 13, 257-267. [CrossRef]

71. Stolz, C.; Hess, G.; Hahnel, P.S.; Grabellus, F.; Hoffarth, S.; Schmid, K.W.; Schuler, M. Targeting Bcl-2 family proteins modulates the sensitivity of B-cell lymphoma to rituximab-induced apoptosis. Blood 2008, 112, 3312-3321. [CrossRef] [PubMed]

72. Jazirehi, A.R.; Vega, M.I.; Bonavida, B. Development of rituximab-resistant lymphoma clones with altered cell signaling and cross-resistance to chemotherapy. Cancer Res. 2007, 67, 1270-1281. [CrossRef] [PubMed]

73. Wenzel, S.S.; Grau, M.; Mavis, C.; Hailfinger, S.; Wolf, A.; Madle, H.; Deeb, G.; Dörken, B.; Thome, M.; Lenz, P.; et al. MCL1 is deregulated in subgroups of diffuse large B-cell lymphoma. Leukemia 2013, 27, 1381-1390. [CrossRef] [PubMed]

74. Dang, C.V. MYC on the path to cancer. Cell 2012, 149, 22-35. [CrossRef]

75. Chisholm, K.M.; Bangs, C.D.; Bacchi, C.E.; Molina-Kirsch, H.; Cherry, A.; Natkunam, Y. Expression profiles of MYC protein and MYC gene rearrangement in lymphomas. Am. J. Surg. Pathol. 2015, 39, 294-303. [CrossRef]

76. Karube, K.; Campo, E. MYC alterations in diffuse large B-cell lymphomas. Semin. Hematol. 2015, 52, 97-106. [CrossRef]

77. Xu-Monette, Z.Y.; Deng, Q.; Manyam, G.C.; Tzankov, A.; Li, L.; Xia, Y.; Wang, X.X.; Zou, D.; Visco, C.; Dybkær, K.; et al. Clinical and Biologic Significance of MYC Genetic Mutations in De Novo Diffuse Large B-cell Lymphoma. Clin. Cancer Res. 2016, 22, 3593-3605. [CrossRef]

78. Savage, K.J.; Johnson, N.A.; Ben-Neriah, S.; Connors, J.M.; Sehn, L.H.; Farinha, P.; Horsman, D.E.; Gascoyne, R.D. MYC gene rearrangements are associated with a poor prognosis in diffuse large B-cell lymphoma patients treated with R-CHOP chemotherapy. Blood 2009, 114, 3533-3537. [CrossRef]

79. Epperla, N.; Maddocks, K.J.; Salhab, M.; Chavez, J.C.; Reddy, N.; Karmali, R.; Umyarova, E.; Bachanova, V.; Costa, C.; Glenn, M.; et al. C-MYC-positive relapsed and refractory, diffuse large B-cell lymphoma: Impact of additional "hits" and outcomes with subsequent therapy. Cancer 2017, 123, 4411-4418. [CrossRef]

80. Hemann, M.T.; Bric, A.; Teruya-Feldstein, J.; Herbst, A.; Nilsson, J.A.; Cordon-Cardo, C.; Cleveland, J.L.; Tansey, W.P.; Lowe, S.W. Evasion of the p53 tumour surveillance network by tumour-derived MYC mutants. Nature 2005, 436, 807-811. [CrossRef]

81. McMahon, S.B. MYC and the control of apoptosis. Cold Spring Harb. Perspect. Med. 2014, 4, a014407. [CrossRef] [PubMed]

82. Yu, L.; Yu, T.T.; Young, K.H. Cross-talk between Myc and p53 in B-cell lymphomas. Chronic Dis. Transl. Med. 2019, 5, 139-154. [CrossRef] [PubMed]

83. Sewastianik, T.; Prochorec-Sobieszek, M.; Chapuy, B.; Juszczyński, P. MYC deregulation in lymphoid tumors: Molecular mechanisms, clinical consequences and therapeutic implications. Biochim. Biophys. Acta 2014, 1846, 457-467. [CrossRef] [PubMed]

84. Eischen, C.M.; Weber, J.D.; Roussel, M.F.; Sherr, C.J.; Cleveland, J.L. Disruption of the ARF-Mdm2-p53 tumor suppressor pathway in Myc-induced lymphomagenesis. Genes Dev. 1999, 13, 2658-2669. [CrossRef] [PubMed]

85. Shaffer, A.L.; Yu, X.; He, Y.; Boldrick, J.; Chan, E.P.; Staudt, L.M. BCL-6 represses genes that function in lymphocyte differentiation, inflammation, and cell cycle control. Immunity 2000, 13, 199-212. [CrossRef]

86. Pasqualucci, L.; Bereshchenko, O.; Niu, H.; Klein, U.; Basso, K.; Guglielmino, R.; Cattoretti, G.; Dalla-Favera, R. Molecular pathogenesis of non-Hodgkin's lymphoma: The role of Bcl-6. Leuk Lymphoma 2003, 44 (Suppl. 3), S5-S12. [CrossRef] 
87. Hatzi, K.; Melnick, A. Breaking bad in the germinal center: How deregulation of BCL6 contributes to lymphomagenesis. Trends Mol. Med. 2014, 20, 343-352. [CrossRef]

88. Li, S.; Wang, Z.; Lin, L.; Wu, Z.; Yu, Q.; Gao, F.; Zhang, J.; Xu, Y. BCL6 Rearrangement Indicates Poor Prognosis in Diffuse Large B-cell Lymphoma Patients: A Meta-analysis of Cohort Studies. J. Cancer 2019, 10, 530-538. [CrossRef]

89. Gebauer, N.; Bernard, V.; Gebauer, W.; Thorns, C.; Feller, A.C.; Merz, H. TP53 mutations are frequent events in double-hit B-cell lymphomas with MYC and BCL2 but not MYC and BCL6 translocations. Leuk Lymphoma 2015, 56, 179-185. [CrossRef]

90. Phan, R.T.; Dalla-Favera, R. The BCL6 proto-oncogene suppresses p53 expression in germinal-centre B cells. Nature 2004, 432, 635-639. [CrossRef]

91. Margalit, O.; Amram, H.; Amariglio, N.; Simon, A.J.; Shaklai, S.; Granot, G.; Minsky, N.; Shimoni, A.; Harmelin, A.; Givol, D.; et al. BCL6 is regulated by p53 through a response element frequently disrupted in B-cell non-Hodgkin lymphoma. Blood 2006, 107, 1599-1607. [CrossRef] [PubMed]

92. Vogelstein, B.; Lane, D.; Levine, A.J. Surfing the p53 network. Nature 2000, 408, 307-310. [CrossRef] [PubMed]

93. Levine, A.J. P53 and The Immune Response: 40 Years of Exploration-A Plan for the Future. Int. J. Mol. Sci. 2020, 21, 541. [CrossRef] [PubMed]

94. Kandoth, C.; McLellan, M.D.; Vandin, F.; Ye, K.; Niu, B.; Lu, C.; Xie, M.; Zhang, Q.; McMichael, J.F.; Wyczalkowski, M.A.; et al. Mutational landscape and significance across 12 major cancer types. Nature 2013, 502, 333-339. [CrossRef] [PubMed]

95. Muller, P.A.; Vousden, K.H. Mutant p53 in cancer: New functions and therapeutic opportunities. Cancer Cell 2014, 25, 304-317. [CrossRef] [PubMed]

96. Stiewe, T.; Haran, T.E. How mutations shape p53 interactions with the genome to promote tumorigenesis and drug resistance. Drug Resist. Updat. 2018, 38, 27-43. [CrossRef] [PubMed]

97. Cao, Y.; Zhu, T.; Zhang, P.; Xiao, M.; Yi, S.; Yang, Y.; Li, Q.; Ling, S.; Wang, Y.; Gao, L.; et al. Mutations or copy number losses of CD58 and TP53 genes in diffuse large B cell lymphoma are independent unfavorable prognostic factors. Oncotarget 2016, 7, 83294-83307. [CrossRef]

98. Zainuddin, N.; Berglund, M.; Wanders, A.; Ren, Z.P.; Amini, R.M.; Lindell, M.; Kanduri, M.; Roos, G.; Rosenquist, R.; Enblad, G. TP53 mutations predict for poor survival in de novo diffuse large B-cell lymphoma of germinal center subtype. Leuk. Res. 2009, 33, 60-66. [CrossRef]

99. Xu-Monette, Z.Y.; Wu, L.; Visco, C.; Tai, Y.C.; Tzankov, A.; Liu, W.M.; Montes-Moreno, S.; Dybkaer, K.; Chiu, A.; Orazi, A.; et al. Mutational profile and prognostic significance of TP53 in diffuse large B-cell lymphoma patients treated with R-CHOP: Report from an International DLBCL Rituximab-CHOP Consortium Program Study. Blood 2012, 120, 3986-3996. [CrossRef]

100. Stefancikova, L.; Moulis, M.; Fabian, P.; Vasova, I.; Zedek, F.; Ravcukova, B.; Muzik, J.; Kuglik, P.; Vranova, V.; Falkova, I.; et al. Prognostic impact of p53 aberrations for R-CHOP-treated patients with diffuse large B-cell lymphoma. Int. J. Oncol. 2011, 39, 1413-1420. [CrossRef]

101. Karube, K.; Enjuanes, A.; Dlouhy, I.; Jares, P.; Martin-Garcia, D.; Nadeu, F.; Ordóñez, G.R.; Rovira, J.; Clot, G.; Royo, C.; et al. Integrating genomic alterations in diffuse large B-cell lymphoma identifies new relevant pathways and potential therapeutic targets. Leukemia 2018, 32, 675-684. [CrossRef] [PubMed]

102. Broseus, J.; Chen, G.; Hergalant, S.; Ramstein, G.; Mounier, N.; Gueant, J.L.; Feugier, P.; Gisselbrecht, C.; Thieblemont, C.; Houlgatte, R. Relapsed diffuse large B-cell lymphoma present different genomic profiles between early and late relapses. Oncotarget 2016, 7, 83987-84002. [CrossRef] [PubMed]

103. Jardin, F.; Jais, J.P.; Molina, T.J.; Parmentier, F.; Picquenot, J.M.; Ruminy, P.; Tilly, H.; Bastard, C.; Salles, G.A.; Feugier, P.; et al. Diffuse large B-cell lymphomas with CDKN2A deletion have a distinct gene expression signature and a poor prognosis under R-CHOP treatment: A GELA study. Blood 2010, 116, 1092-1104. [CrossRef] [PubMed]

104. Hientz, K.; Mohr, A.; Bhakta-Guha, D.; Efferth, T. The role of p53 in cancer drug resistance and targeted chemotherapy. Oncotarget 2017, 8, 8921-8946. [CrossRef] [PubMed]

105. Ho, T.; Tan, B.X.; Lane, D. How the Other Half Lives: What p53 Does When It Is Not Being a Transcription Factor. Int. J. Mol. Sci. 2019, 21, 13. [CrossRef]

106. Blagih, J.; Buck, M.D.; Vousden, K.H. p53, cancer and the immune response. J. Cell Sci. 2020, 133, jcs237453. [CrossRef] 
107. Rawlings, J.S.; Rosler, K.M.; Harrison, D.A. The JAK/STAT signaling pathway. J. Cell Sci. 2004, 117, 1281-1283. [CrossRef]

108. Villarino, A.V.; Kanno, Y.; O'Shea, J.J. Mechanisms and consequences of Jak-STAT signaling in the immune system. Nat. Immunol. 2017, 18, 374-384. [CrossRef]

109. Morris, R.; Kershaw, N.J.; Babon, J.J. The molecular details of cytokine signaling via the JAK/STAT pathway. Protein Sci. 2018, 27, 1984-2009. [CrossRef]

110. Turkson, J. STAT proteins as novel targets for cancer drug discovery. Expert Opin. Ther. Targets 2004, 8, 409-422. [CrossRef]

111. Saint-Germain, E.; Mignacca, L.; Huot, G.; Acevedo, M.; Moineau-Vallée, K.; Calabrese, V.; Bourdeau, V.; Rowell, M.C.; Ilangumaran, S.; Lessard, F.; et al. Phosphorylation of SOCS1 Inhibits the SOCS1-p53 Tumor Suppressor Axis. Cancer Res. 2019, 79, 3306-3319. [CrossRef]

112. Beaurivage, C.; Champagne, A.; Tobelaim, W.S.; Pomerleau, V.; Menendez, A.; Saucier, C. SOCS1 in cancer: An oncogene and a tumor suppressor. Cytokine 2016, 82, 87-94. [CrossRef] [PubMed]

113. Schif, B.; Lennerz, J.K.; Kohler, C.W.; Bentink, S.; Kreuz, M.; Melzner, I.; Ritz, O.; Trümper, L.; Loeffler, M.; Spang, R.; et al. SOCS1 mutation subtypes predict divergent outcomes in diffuse large B-Cell lymphoma (DLBCL) patients. Oncotarget 2013, 4, 35-47. [CrossRef] [PubMed]

114. Mellert, K.; Martin, M.; Lennerz, J.K.; Lüdeke, M.; Staiger, A.M.; Kreuz, M.; Löffler, M.; Schmitz, N.; Trümper, L.; Feller, A.C.; et al. The impact of SOCS1 mutations in diffuse large B-cell lymphoma. Br. J. Haematol. 2019, 187, 627-637. [CrossRef] [PubMed]

115. Lam, L.T.; Wright, G.; Davis, R.E.; Lenz, G.; Farinha, P.; Dang, L.; Chan, J.W.; Rosenwald, A.; Gascoyne, R.D.; Staudt, L.M. Cooperative signaling through the signal transducer and activator of transcription 3 and nuclear factor-\{kappa\}B pathways in subtypes of diffuse large B-cell lymphoma. Blood 2008, 111, 3701-3713. [CrossRef] [PubMed]

116. Lu, L.; Zhu, F.; Zhang, M.; Li, Y.; Drennan, A.C.; Kimpara, S.; Rumball, I.; Selzer, C.; Cameron, H.; Kellicut, A.; et al. Gene regulation and suppression of type I interferon signaling by STAT3 in diffuse large B cell lymphoma. Proc. Natl. Acad. Sci. USA 2018, 115, E498-e505. [CrossRef] [PubMed]

117. de Charette, M.; Houot, R. Hide or defend, the two strategies of lymphoma immune evasion: Potential implications for immunotherapy. Haematologica 2018, 103, 1256-1268. [CrossRef] [PubMed]

118. Menter, T.; Tzankov, A. Mechanisms of Immune Evasion and Immune Modulation by Lymphoma Cells. Front. Oncol. 2018, 8, 54. [CrossRef] [PubMed]

119. Garrido, F.; Aptsiauri, N.; Doorduijn, E.M.; Garcia Lora, A.M.; van Hall, T. The urgent need to recover MHC class I in cancers for effective immunotherapy. Curr. Opin. Immunol. 2016, 39, 44-51. [CrossRef]

120. Williams, D.; Barber, B.; Flavell, R.; Allen, H. Role of beta 2-microglobulin in the intracellular transport and surface expression of murine class I histocompatibility molecules. J. Immunol. 1989, 142, 2796-2806.

121. Ennishi, D.; Takata, K.; Béguelin, W.; Duns, G.; Mottok, A.; Farinha, P.; Bashashati, A.; Saberi, S.; Boyle, M.; Meissner, B.; et al. Molecular and Genetic Characterization of MHC Deficiency Identifies EZH2 as Therapeutic Target for Enhancing Immune Recognition. Cancer Discov. 2019, 9, 546-563. [CrossRef] [PubMed]

122. Zaretsky, J.M.; Garcia-Diaz, A.; Shin, D.S.; Escuin-Ordinas, H.; Hugo, W.; Hu-Lieskovan, S.; Torrejon, D.Y.; Abril-Rodriguez, G.; Sandoval, S.; Barthly, L.; et al. Mutations Associated with Acquired Resistance to PD-1 Blockade in Melanoma. N. Engl. J. Med. 2016, 375, 819-829. [CrossRef] [PubMed]

123. Sade-Feldman, M.; Jiao, Y.J.; Chen, J.H.; Rooney, M.S.; Barzily-Rokni, M.; Eliane, J.P.; Bjorgaard, S.L.; Hammond, M.R.; Vitzthum, H.; Blackmon, S.M.; et al. Resistance to checkpoint blockade therapy through inactivation of antigen presentation. Nat. Commun. 2017, 8, 1136. [CrossRef] [PubMed]

124. Middha, S.; Yaeger, R.; Shia, J.; Stadler, Z.K.; King, S.; Guercio, S.; Paroder, V.; Bates, D.D.; Rana, S.; Diaz Jr, L.A. Majority of B2M-mutant and-deficient colorectal carcinomas achieve clinical benefit from immune checkpoint inhibitor therapy and are microsatellite instability-high. JCO Precis. Oncol. 2019, 3, 1-14. [CrossRef]

125. Kiyasu, J.; Miyoshi, H.; Hirata, A.; Arakawa, F.; Ichikawa, A.; Niino, D.; Sugita, Y.; Yufu, Y.; Choi, I.; Abe, Y.; et al. Expression of programmed cell death ligand 1 is associated with poor overall survival in patients with diffuse large B-cell lymphoma. Blood 2015, 126, 2193-2201. [CrossRef]

126. Fang, X.; Xiu, B.; Yang, Z.; Qiu, W.; Zhang, L.; Zhang, S.; Wu, Y.; Zhu, X.; Chen, X.; Xie, S.; et al. The expression and clinical relevance of PD-1, PD-L1, and TP63 in patients with diffuse large B-cell lymphoma. Medicine (Baltimore) 2017, 96, e6398. [CrossRef] 
127. Godfrey, J.; Tumuluru, S.; Bao, R.; Leukam, M.; Venkataraman, G.; Phillip, J.; Fitzpatrick, C.; McElherne, J.; MacNabb, B.W.; Orlowski, R.; et al. PD-L1 gene alterations identify a subset of diffuse large B-cell lymphoma harboring a T-cell-inflamed phenotype. Blood 2019, 133, 2279-2290. [CrossRef]

128. Challa-Malladi, M.; Lieu, Y.K.; Califano, O.; Holmes, A.B.; Bhagat, G.; Murty, V.V.; Dominguez-Sola, D.; Pasqualucci, L.; Dalla-Favera, R. Combined genetic inactivation of beta2-Microglobulin and CD58 reveals frequent escape from immune recognition in diffuse large B cell lymphoma. Cancer Cell 2011, 20, 728-740. [CrossRef]

129. Sanchez-Madrid, F.; Krensky, A.M.; Ware, C.F.; Robbins, E.; Strominger, J.L.; Burakoff, S.J.; Springer, T.A. Three distinct antigens associated with human T-lymphocyte-mediated cytolysis: LFA-1, LFA-2, and LFA-3. Proc. Natl. Acad. Sci. USA 1982, 79, 7489-7493. [CrossRef]

130. Krensky, A.M.; Sanchez-Madrid, F.; Robbins, E.; Nagy, J.A.; Springer, T.A.; Burakoff, S.J. The functional significance, distribution, and structure of LFA-1, LFA-2, and LFA-3: Cell surface antigens associated with CTL-target interactions. J. Immunol. 1983, 131, 611-616.

131. Selvaraj, P.; Plunkett, M.L.; Dustin, M.; Sanders, M.E.; Shaw, S.; Springer, T.A. The T lymphocyte glycoprotein CD2 binds the cell surface ligand LFA-3. Nature 1987, 326, 400-403. [CrossRef] [PubMed]

132. Otsuka, Y.; Nishikori, M.; Arima, H.; Izumi, K.; Kitawaki, T.; Hishizawa, M.; Takaori-Kondo, A. EZH2 inhibitors restore epigenetically silenced CD58 expression in B-cell lymphomas. Mol. Immunol. 2020, 119, 35-45. [CrossRef] [PubMed]

133. Miao, Y.; Medeiros, L.J.; Li, Y.; Li, J.; Young, K.H. Genetic alterations and their clinical implications in DLBCL. Nat. Rev. Clin. Oncol. 2019, 16, 634-652. [CrossRef] [PubMed]

134. Klemm, S.L.; Shipony, Z.; Greenleaf, W.J. Chromatin accessibility and the regulatory epigenome. Nat. Rev. Genet 2019, 20, 207-220. [CrossRef]

135. Hamamoto, R.; Saloura, V.; Nakamura, Y. Critical roles of non-histone protein lysine methylation in human tumorigenesis. Nat. Rev. Cancer 2015, 15, 110-124. [CrossRef]

136. Mullighan, C.G.; Zhang, J.; Kasper, L.H.; Lerach, S.; Payne-Turner, D.; Phillips, L.A.; Heatley, S.L.; Holmfeldt, L.; Collins-Underwood, J.R.; Ma, J.; et al. CREBBP mutations in relapsed acute lymphoblastic leukaemia. Nature 2011, 471, 235-239. [CrossRef]

137. Froimchuk, E.; Jang, Y.; Ge, K. Histone H3 lysine 4 methyltransferase KMT2D. Gene 2017, 627, $337-342$. [CrossRef]

138. Lee, J.; Kim, D.H.; Lee, S.; Yang, Q.H.; Lee, D.K.; Lee, S.K.; Roeder, R.G.; Lee, J.W. A tumor suppressive coactivator complex of p53 containing ASC-2 and histone H3-lysine-4 methyltransferase MLL3 or its paralogue MLL4. Proc. Natl. Acad. Sci. USA 2009, 106, 8513-8518. [CrossRef]

139. Béguelin, W.; Teater, M.; Meydan, C.; Hoehn, K.B.; Phillip, J.M.; Soshnev, A.A.; Venturutti, L.; Rivas, M.A.; Calvo-Fernández, M.T.; Gutierrez, J.; et al. Mutant EZH2 Induces a Pre-malignant Lymphoma Niche by Reprogramming the Immune Response. Cancer Cell 2020, 37, 655-673.e611. [CrossRef]

140. Pasqualucci, L.; Dominguez-Sola, D.; Chiarenza, A.; Fabbri, G.; Grunn, A.; Trifonov, V.; Kasper, L.H.; Lerach, S.; Tang, H.; Ma, J.; et al. Inactivating mutations of acetyltransferase genes in B-cell lymphoma. Nature 2011, 471, 189-195. [CrossRef] [PubMed]

141. Liu, Y.; Barta, S.K. Diffuse large B-cell lymphoma: 2019 update on diagnosis, risk stratification, and treatment. Am. J. Hematol. 2019, 94, 604-616. [CrossRef] [PubMed]

142. Mondello, P.; Nowakowski, G.S. Treatment of Aggressive B Cell Lymphomas: Updates in 2019. Curr. Hematol. Malig. Rep. 2020, 15, 225-234. [CrossRef] [PubMed]

143. Kater, A.P.; Seymour, J.F.; Hillmen, P.; Eichhorst, B.; Langerak, A.W.; Owen, C.; Verdugo, M.; Wu, J.; Punnoose, E.A.; Jiang, Y.; et al. Fixed Duration of Venetoclax-Rituximab in Relapsed/Refractory Chronic Lymphocytic Leukemia Eradicates Minimal Residual Disease and Prolongs Survival: Post-Treatment Follow-Up of the MURANO Phase III Study. J. Clin. Oncol. 2019, 37, 269-277. [CrossRef] [PubMed]

144. Guerra, V.A.; DiNardo, C.; Konopleva, M. Venetoclax-based therapies for acute myeloid leukemia. Best Pract. Res. Clin. Haematol. 2019, 32, 145-153. [CrossRef] [PubMed]

145. Roberts, A.W.; Davids, M.S.; Pagel, J.M.; Kahl, B.S.; Puvvada, S.D.; Gerecitano, J.F.; Kipps, T.J.; Anderson, M.A.; Brown, J.R.; Gressick, L.; et al. Targeting BCL2 with Venetoclax in Relapsed Chronic Lymphocytic Leukemia. N. Engl. J. Med. 2016, 374, 311-322. [CrossRef] [PubMed] 
146. Zelenetz, A.D.; Salles, G.; Mason, K.D.; Casulo, C.; Le Gouill, S.; Sehn, L.H.; Tilly, H.; Cartron, G.; Chamuleau, M.E.D.; Goy, A.; et al. Venetoclax plus R- or G-CHOP in non-Hodgkin lymphoma: Results from the CAVALLI phase 1b trial. Blood 2019, 133, 1964-1976. [CrossRef]

147. Morschhauser, F.; Feugier, P.; Flinn, I.W.; Gasiorowski, R.; Greil, R.; Illes, A.; Johnson, N.A.; Larouche, J.F.; Lugtenburg, P.J.; Patti, C.; et al. A phase II study of venetoclax plus R-CHOP as first-line treatment for patients with diffuse large B-cell lymphoma. Blood 2020. [CrossRef]

148. Bose, P.; Gandhi, V.; Konopleva, M. Pathways and mechanisms of venetoclax resistance. Leuk Lymphoma 2017, 58, 1-17. [CrossRef]

149. Liu, Y.; Mondello, P.; Erazo, T.; Tannan, N.B.; Asgari, Z.; de Stanchina, E.; Nanjangud, G.; Seshan, V.E.; Wang, S.; Wendel, H.G.; et al. NOXA genetic amplification or pharmacologic induction primes lymphoma cells to BCL2 inhibitor-induced cell death. Proc. Natl. Acad. Sci. USA 2018, 115, 12034-12039. [CrossRef]

150. Li, L.; Pongtornpipat, P.; Tiutan, T.; Kendrick, S.L.; Park, S.; Persky, D.O.; Rimsza, L.M.; Puvvada, S.D.; Schatz, J.H. Synergistic induction of apoptosis in high-risk DLBCL by BCL2 inhibition with ABT-199 combined with pharmacologic loss of MCL1. Leukemia 2015, 29, 1702-1712. [CrossRef]

151. Choudhary, G.S.; Al-Harbi, S.; Mazumder, S.; Hill, B.T.; Smith, M.R.; Bodo, J.; Hsi, E.D.; Almasan, A. MCL-1 and BCL-xL-dependent resistance to the BCL-2 inhibitor ABT-199 can be overcome by preventing PI3K/AKT/mTOR activation in lymphoid malignancies. Cell Death Dis. 2015, 6, e1593. [CrossRef] [PubMed]

152. Sun, K.; Atoyan, R.; Borek, M.A.; Dellarocca, S.; Rhyasen, G.; Fattaey, A.; Tuck, D.P. The combination of venetoclax and CUDC-907 exhibits synergistic activity in venetoclax-refractory DLBCL. Blood 2016, 128, 4184. [CrossRef]

153. Mondello, P.; Derenzini, E.; Asgari, Z.; Philip, J.; Brea, E.J.; Seshan, V.; Hendrickson, R.C.; de Stanchina, E.; Scheinberg, D.A.; Younes, A. Dual inhibition of histone deacetylases and phosphoinositide 3-kinase enhances therapeutic activity against B cell lymphoma. Oncotarget 2017, 8, 14017-14028. [CrossRef] [PubMed]

154. Li, W.; Gupta, S.K.; Han, W.; Kundson, R.A.; Nelson, S.; Knutson, D.; Greipp, P.T.; Elsawa, S.F.; Sotomayor, E.M.; Gupta, M. Targeting MYC activity in double-hit lymphoma with MYC and BCL2 and/or BCL6 rearrangements with epigenetic bromodomain inhibitors. J. Hematol. Oncol. 2019, 12, 73. [CrossRef]

155. Mottok, A.; Gascoyne, R.D. Bromodomain inhibition in diffuse large B-cell lymphoma-Giving MYC a brake. Clin. Cancer Res. 2015, 21, 4-6. [CrossRef]

156. Delmore, J.E.; Issa, G.C.; Lemieux, M.E.; Rahl, P.B.; Shi, J.; Jacobs, H.M.; Kastritis, E.; Gilpatrick, T.; Paranal, R.M.; Qi, J. BET bromodomain inhibition as a therapeutic strategy to target c-Myc. Cell 2011, 146, 904-917. [CrossRef]

157. Kumar, A.; Marqués, M.; Carrera, A.C. Phosphoinositide 3-kinase activation in late G1 is required for c-Myc stabilization and S phase entry. Mol. Cell Biol. 2006, 26, 9116-9125. [CrossRef]

158. Fjorden, K.; Ekberg, S.; Kuric, N.; Ekstroem Smedby, K.; Lagerlöf, I.; Larsen, T.S.; Jørgensen, J.M.; Brown, P.d.N.; Jerkeman, M. Idelalisib in Patients with Relapsed/Refractory Diffuse Large B-Cell Lymphoma: First Results from the Nordic Lymphoma Group NLG-LBC-07 (ILIAD) Phase II Trial. Blood 2020, 136, 33. [CrossRef]

159. Oki, Y.; Kelly, K.R.; Flinn, I.; Patel, M.R.; Gharavi, R.; Ma, A.; Parker, J.; Hafeez, A.; Tuck, D.; Younes, A. CUDC-907 in relapsed/refractory diffuse large B-cell lymphoma, including patients with MYC-alterations: Results from an expanded phase I trial. Haematologica 2017, 102, 1923-1930. [CrossRef]

160. Jung, H.-S.; Kim, N.H.; Wang, J.; Son, M.K.; Kim, B.-K.; Jeon, B.; Choi, Y.; Myung, J.; Kim, D.-H. Combination of BR101801 and venetoclax demonstrates synergistic activity in DLBCL cell lines harboring double hit and double expressor alterations. Blood 2017, 130, 4114.

161. Bykov, V.J.N.; Eriksson, S.E.; Bianchi, J.; Wiman, K.G. Targeting mutant p53 for efficient cancer therapy. Nat. Rev. Cancer 2018, 18, 89-102. [CrossRef] [PubMed]

162. Levine, A.J. Targeting therapies for the p53 protein in cancer treatments. Annu. Rev. Cancer Biol. 2019, 3, 21-34. [CrossRef]

163. Duffy, M.J.; Synnott, N.C.; Crown, J. Mutant p53 as a target for cancer treatment. Eur. J. Cancer 2017, 83, 258-265. [CrossRef] [PubMed]

164. Liu, Y.; Tavana, O.; Gu, W. p53 modifications: Exquisite decorations of the powerful guardian. J. Mol. Cell Biol. 2019, 11, 564-577. [CrossRef] [PubMed] 
165. Drakos, E.; Singh, R.R.; Rassidakis, G.Z.; Schlette, E.; Li, J.; Claret, F.X.; Ford, R.J., Jr.; Vega, F.; Medeiros, L.J. Activation of the p53 pathway by the MDM2 inhibitor nutlin-3a overcomes BCL2 overexpression in a preclinical model of diffuse large B-cell lymphoma associated with $\mathrm{t}(14 ; 18)$ (q32;q21). Leukemia 2011, 25, 856-867. [CrossRef] [PubMed]

166. Tisato, V.; Voltan, R.; Gonelli, A.; Secchiero, P.; Zauli, G. MDM2/X inhibitors under clinical evaluation: Perspectives for the management of hematological malignancies and pediatric cancer. J. Hematol. Oncol. 2017, 10, 133. [CrossRef]

167. Ng, S.Y.; Yoshida, N.; Christie, A.L.; Ghandi, M.; Dharia, N.V.; Dempster, J.; Murakami, M.; Shigemori, K.; Morrow, S.N.; Van Scoyk, A.; et al. Targetable vulnerabilities in T- and NK-cell lymphomas identified through preclinical models. Nat. Commun. 2018, 9, 2024. [CrossRef]

168. Cheok, C.F.; Lane, D.P. Exploiting the p53 Pathway for Therapy. Cold Spring Harb. Perspect. Med. $2017,7$. [CrossRef]

169. Gadina, M.; Johnson, C.; Schwartz, D.; Bonelli, M.; Hasni, S.; Kanno, Y.; Changelian, P.; Laurence, A.; O'Shea, J.J. Translational and clinical advances in JAK-STAT biology: The present and future of jakinibs. J. Leukoc. Biol. 2018, 104, 499-514. [CrossRef]

170. Drennan, A.C.; Rui, L. HiJAKing the epigenome in leukemia and lymphoma. Leuk Lymphoma 2017, 58, 2540-2547. [CrossRef]

171. Phillips, T.J.; Forero-Torres, A.; Sher, T.; Diefenbach, C.S.; Johnston, P.; Talpaz, M.; Pulini, J.; Zhou, L.; Scherle, P.; Chen, X.; et al. Phase 1 study of the PI3K $\delta$ inhibitor INCB040093 \pm JAK1 inhibitor itacitinib in relapsed/refractory B-cell lymphoma. Blood 2018, 132, 293-306. [CrossRef] [PubMed]

172. O'Shea, J.J.; Schwartz, D.M.; Villarino, A.V.; Gadina, M.; McInnes, I.B.; Laurence, A. The JAK-STAT pathway: Impact on human disease and therapeutic intervention. Annu. Rev. Med. 2015, 66, 311-328. [CrossRef] [PubMed]

173. Heppler, L.N.; Frank, D.A. Targeting Oncogenic Transcription Factors: Therapeutic Implications of Endogenous STAT Inhibitors. Trends Cancer 2017, 3, 816-827. [CrossRef] [PubMed]

174. Del Campo, A.; Carretero, J.; Muñoz, J.; Zinchenko, S.; Ruiz-Cabello, F.; Gonzalez-Aseguinolaza, G.; Garrido, F.; Aptsiauri, N. Adenovirus expressing $\beta 2$-microglobulin recovers HLA class I expression and antitumor immunity by increasing T-cell recognition. Cancer Gene Ther. 2014, 21, 317-332. [CrossRef]

175. Neelapu, S.S.; Locke, F.L.; Bartlett, N.L.; Lekakis, L.J.; Miklos, D.B.; Jacobson, C.A.; Braunschweig, I.; Oluwole, O.O.; Siddiqi, T.; Lin, Y.; et al. Axicabtagene Ciloleucel CAR T-Cell Therapy in Refractory Large B-Cell Lymphoma. N. Engl. J. Med. 2017, 377, 2531-2544. [CrossRef]

176. Schuster, S.J.; Bishop, M.R.; Tam, C.S.; Waller, E.K.; Borchmann, P.; McGuirk, J.P.; Jäger, U.; Jaglowski, S.; Andreadis, C.; Westin, J.R.; et al. Tisagenlecleucel in Adult Relapsed or Refractory Diffuse Large B-Cell Lymphoma. N. Engl. J. Med. 2019, 380, 45-56. [CrossRef]

177. Gonzalez-Rodriguez, A.P.; Villa-Álvarez, M.; Sordo-Bahamonde, C.; Lorenzo-Herrero, S.; Gonzalez, S. NK Cells in the Treatment of Hematological Malignancies. J. Clin. Med. 2019, 8, 1557. [CrossRef]

178. Ansell, S.M.; Minnema, M.C.; Johnson, P.; Timmerman, J.M.; Armand, P.; Shipp, M.A.; Rodig, S.J.; Ligon, A.H.; Roemer, M.G.M.; Reddy, N.; et al. Nivolumab for Relapsed/Refractory Diffuse Large B-Cell Lymphoma in Patients Ineligible for or Having Failed Autologous Transplantation: A Single-Arm, Phase II Study. J. Clin. Oncol. 2019, 37, 481-489. [CrossRef]

179. Herrera, A.F.; Goy, A.; Mehta, A.; Ramchandren, R.; Pagel, J.M.; Svoboda, J.; Guan, S.; Hill, J.S.; Kwei, K.; Liu, E.A.; et al. Safety and activity of ibrutinib in combination with durvalumab in patients with relapsed or refractory follicular lymphoma or diffuse large B-cell lymphoma. Am. J. Hematol. 2020, 95, 18-27. [CrossRef]

180. Ribeiro, M.L.; Reyes-Garau, D.; Armengol, M.; Fernández-Serrano, M.; Roué, G. Recent advances in the targeting of epigenetic regulators in B-cell non-Hodgkin lymphoma. Front. Genet. 2019, 10, 986. [CrossRef]

181. Duan, H.; Heckman, C.A.; Boxer, L.M. Histone deacetylase inhibitors down-regulate bcl-2 expression and induce apoptosis in $\mathrm{t}(14 ; 18)$ lymphomas. Mol. Cell Biol. 2005, 25, 1608-1619. [CrossRef] [PubMed]

182. Kurland, J.F.; Tansey, W.P. Myc-mediated transcriptional repression by recruitment of histone deacetylase. Cancer Res. 2008, 68, 3624-3629. [CrossRef]

183. Zhang, X.; Zhao, X.; Fiskus, W.; Lin, J.; Lwin, T.; Rao, R.; Zhang, Y.; Chan, J.C.; Fu, K.; Marquez, V.E.; et al. Coordinated silencing of MYC-mediated miR-29 by HDAC3 and EZH2 as a therapeutic target of histone modification in aggressive B-Cell lymphomas. Cancer Cell 2012, 22, 506-523. [CrossRef] [PubMed]

184. Bereshchenko, O.R.; Gu, W.; Dalla-Favera, R. Acetylation inactivates the transcriptional repressor BCL6. Nat. Genet. 2002, 32, 606-613. [CrossRef] [PubMed] 
185. Crump, M.; Coiffier, B.; Jacobsen, E.D.; Sun, L.; Ricker, J.L.; Xie, H.; Frankel, S.R.; Randolph, S.S.; Cheson, B.D. Phase II trial of oral vorinostat (suberoylanilide hydroxamic acid) in relapsed diffuse large-B-cell lymphoma. Ann. Oncol. 2008, 19, 964-969. [CrossRef] [PubMed]

186. Barnes, J.A.; Redd, R.; Fisher, D.C.; Hochberg, E.P.; Takvorian, T.; Neuberg, D.; Jacobsen, E.; Abramson, J.S. Panobinostat in combination with rituximab in heavily pretreated diffuse large B-cell lymphoma: Results of a phase II study. Hematol. Oncol. 2018, 36, 633-637. [CrossRef] [PubMed]

187. Ribrag, V.; Kim, W.S.; Bouabdallah, R.; Lim, S.T.; Coiffier, B.; Illes, A.; Lemieux, B.; Dyer, M.J.S.; Offner, F.; Felloussi, Z; et al. Safety and efficacy of abexinostat, a pan-histone deacetylase inhibitor, in non-Hodgkin lymphoma and chronic lymphocytic leukemia: Results of a phase II study. Haematologica 2017, 102, 903-909. [CrossRef] [PubMed]

188. Amengual, J.E.; Clark-Garvey, S.; Kalac, M.; Scotto, L.; Marchi, E.; Neylon, E.; Johannet, P.; Wei, Y.; Zain, J.; O'Connor, O.A. Sirtuin and pan-class I/II deacetylase (DAC) inhibition is synergistic in preclinical models and clinical studies of lymphoma. Blood 2013, 122, 2104-2113. [CrossRef]

189. Dai, C.; Gu, W. p53 post-translational modification: Deregulated in tumorigenesis. Trends Mol. Med. 2010, 16, 528-536. [CrossRef]

190. Lue, J.K.; Amengual, J.E. Emerging EZH2 inhibitors and their application in lymphoma. Current Hematol. Malig. Rep. 2018, 13, 369-382. [CrossRef]

191. McCabe, M.T.; Ott, H.M.; Ganji, G.; Korenchuk, S.; Thompson, C.; Van Aller, G.S.; Liu, Y.; Graves, A.P.; Della Pietra, A., 3rd; Diaz, E.; et al. EZH2 inhibition as a therapeutic strategy for lymphoma with EZH2-activating mutations. Nature 2012, 492, 108-112. [CrossRef] [PubMed]

192. Béguelin, W.; Popovic, R.; Teater, M.; Jiang, Y.; Bunting, K.L.; Rosen, M.; Shen, H.; Yang, S.N.; Wang, L.; Ezponda, T.; et al. EZH2 is required for germinal center formation and somatic EZH2 mutations promote lymphoid transformation. Cancer Cell 2013, 23, 677-692. [CrossRef] [PubMed]

193. Plch, J.; Hrabeta, J.; Eckschlager, T. KDM5 demethylases and their role in cancer cell chemoresistance. Int. J. Cancer 2019, 144, 221-231. [CrossRef] [PubMed]

194. Heward, J.; Koniali, L.; D’Avola, A.; Close, K.; Yeomans, A.; Johnson, P.; Okosun, J.; Neve, R.; Gribben, J.; Oppermann, U. S844 KDM5 inhibition offers a novel therapeutic strategy for the treatment of kmt2d mutant lymphomas. HemaSphere 2019, 3, 376-377. [CrossRef]

Publisher's Note: MDPI stays neutral with regard to jurisdictional claims in published maps and institutional affiliations.

(C) 2020 by the authors. Licensee MDPI, Basel, Switzerland. This article is an open access article distributed under the terms and conditions of the Creative Commons Attribution (CC BY) license (http://creativecommons.org/licenses/by/4.0/). 